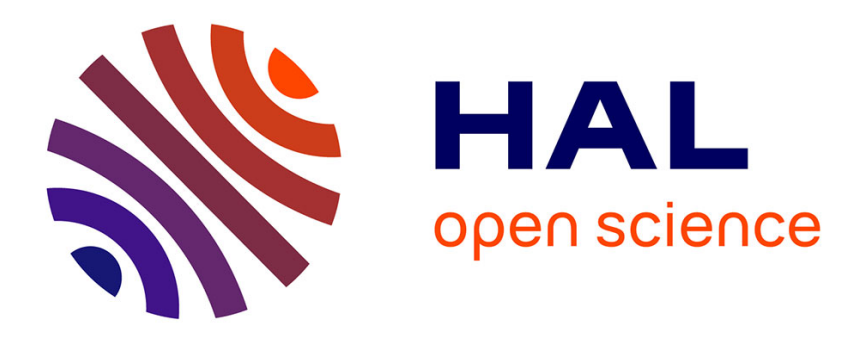

\title{
Sensing and signalling viral infection in drosophila
}

Juliette Schneider, Jean-Luc Imler

\section{To cite this version:}

Juliette Schneider, Jean-Luc Imler. Sensing and signalling viral infection in drosophila. Developmental and Comparative Immunology, 2021, 117, pp.103985. 10.1016/j.dci.2020.103985 . hal-03115893

\section{HAL Id: hal-03115893 \\ https://hal.science/hal-03115893}

Submitted on 19 Jan 2021

HAL is a multi-disciplinary open access archive for the deposit and dissemination of scientific research documents, whether they are published or not. The documents may come from teaching and research institutions in France or abroad, or from public or private research centers.
L'archive ouverte pluridisciplinaire HAL, est destinée au dépôt et à la diffusion de documents scientifiques de niveau recherche, publiés ou non, émanant des établissements d'enseignement et de recherche français ou étrangers, des laboratoires publics ou privés. 
Sensing and signalling viral infection in Drosophila

Juliette Schneider \& Jean-Luc Imler

\section{Highlights}

- $\quad$ siRNAs and miRNAs, but not piRNAs, regulate viral infection in drosophila.

- $\quad \mathrm{NF}-\kappa \mathrm{B}$ mediated inducible responses contribute to antiviral immunity in flies.

- Drosophila can be used to decipher the ancestral role of STING in antiviral immunity. 
4 Sensing and signalling viral infection in Drosophila

5

6 Juliette Schneider ${ }^{1}$ \& Jean-Luc Imler ${ }^{1,2,{ }^{*}}$

7

8

9

10

111 Université de Strasbourg, CNRS UPR9022, Institut de Biologie Moléculaire et

12 Cellulaire, Strasbourg, France

132 Sino-French Hoffmann Institute, School of Basic Medical Science, Guangzhou

14 Medical University, Guangzhou 511436, China

15

16

*Correspondance : jl.imler@ibmc-cnrs.unistra.fr

17

18 


\section{Abstract:}

The fruitfly Drosophila melanogaster is a valuable model to unravel mechanisms

21 of innate immunity, in particular in the context of viral infections. RNA interference, and more specifically the small interfering RNA pathway, is a major component of antiviral 23 immunity in drosophila. In addition, the contribution of inducible transcriptional 5 responses to the control of viruses in drosophila and other invertebrates is increasingly recognized. In particular, the recent discovery of a STING-IKK $\beta$-Relish signalling cassette in drosophila has confirmed that NF-кB transcription factors play an important role in the control of viral infections, in addition to bacterial and fungal infections. Here, we review recent developments in the field, which begin to shed light on the mechanisms involved in sensing of viral infections and in signalling leading to production of antiviral effectors.

Keywords:

NF-кB; STING; RNA interference; innate immunity; antiviral factors; virus 


\section{Introduction}

(1)

All living organisms face viral infections during their lifetime. To defend themselves, hosts developed various antiviral immune responses throughout evolution. In this regard, insects represent an interesting opportunity, in light of the fantastic biodiversity they represent, with over 1 million known species and an evolutionary history covering 350 million years (Misof et al., 2014). Historically, insect-virus interactions were first studied in the context of diseases affecting economically important insects, such as silkworms (Lü et al., 2018) or bees (Manley et al., 2015). Insect viruses also rapidly became of interest as biological control agents (e.g. baculoviruses (Lacey et al., 2015)). Finally, important animal and human viral diseases are transmitted by Culex and Aedes mosquitoes, e.g. West Nile, Yellow Fever, Dengue, Zika and Chikungunya (Shaw and Catteruccia, 2019). Pioneering studies in drosophila and genome sequencing have, since the early 2000 s, promoted the expansion of the field of insect antiviral immunity.

Among insects, the fruit fly Drosophila melanogaster has a special status as an invaluable model organism, used since the beginning of the $X X^{\text {th }}$ century to understand the genetic basis of heredity, embryonic development as well as a range of biomedical problems, including immunity (reviewed in (Wangler et al., 2015)). Research on drosophila host defence against bacterial and fungal infections led to the identification of two evolutionarily conserved signalling pathways, Toll and Immune deficiency (IMD), regulating transcription factors of the $\mathrm{NF}-\kappa \mathrm{B}$ family to induce production of antimicrobial peptides (AMPs; reviewed in (Hoffmann et al., 1999; Hultmark, 2003; Lemaitre and Hoffmann, 2007)). Cellular responses, driven by hemocytes, also participate in the control of infections (Gold and Brückner, 2015; Lamiable et al., 2016a; Letourneau et 
al., 2016; Nainu et al., 2015; Weavers et al., 2016). More recently, the interest for antiviral resistance mechanisms in drosophila has grown, initially taking advantage of the pioneering work of Philippe Lhéritier and Nadine Plus who described the first drosophila viruses, Sigma virus and Drosophila C virus (DCV, Table 1 (Jousset et al., 1972; Lhéritier, 1958)). This led to the identification of the first genes encoding restriction factors (e.g. (Cao et al., 2017, 2016; Gay, 1978)), the description of induced responses (e.g. (Dostert et al., 2005; Kemp et al., 2013; Merkling et al., 2015b; Xu et al., 2012)), the discovery of the important role of RNA interference (RNAi ((GalianaArnoux et al., 2006; van Rij et al., 2006; Wang et al., 2006)) and the characterization of evolutionarily conserved host factors used by viruses or participating in the control of infections (e.g. (Eleftherianos et al., 2011; Majzoub et al., 2014; Panda et al., 2013)). In addition, the characterization of the drosophila virome led to the discovery of more than 20 new viruses, which represent a goldmine for future studies on virus-host interactions (Webster et al., 2015). Especially, the first natural DNA virus of Drosophila melanogaster, Kallithea virus (KV, Table 1), has been described and characterised (Palmer et al., 2018a).

Research carried on the genetics of drosophila antiviral immunity over the past 15 years led to the identification of many genes and pathways associated with host restriction factors, inducible responses and antiviral RNA interference (RNAi), which have been reviewed (Chow and Kagan, 2018; Liu et al., 2017; Mondotte and Saleh, 2018; Mussabekova et al., 2017; Palmer et al., 2018b; Segrist and Cherry, 2020; Swevers et al., 2018; Talide et al., 2020). Here, we focus on the recent advances in the field with a particular focus on the latest developments on RNA-based antiviral defences (RNAi) and on inducible responses. We also discuss remaining questions to better understand drosophila defences against viruses. 
RNAi, initially identified as a major antiviral pathway in plants, also plays an important role in drosophila immunity (reviewed in (Guo et al., 2019)). Small RNA silencing encompasses three different pathways in flies (Ghildiyal and Zamore, 2009), each of which participates in host-virus interaction, albeit at different levels. Two of these pathways involve small RNAs produced by Dicer (Dcr) enzymes, the 22-23nt long micro (mi) RNAs produced by Dcr-1 and the 21nt-long small interfering (si) RNAs produced by Dcr-2. Dicers are RNaselll enzymes that process double-stranded (ds) RNA precursors into small RNA duplexes. In the case of miRNAs, a complex composed of another RNase III enzyme, Drosha, and a dsRNA binding protein (dsRBP), Pasha, processes the primary transcripts of mi-RNA (pri-miRNA) in the nucleus. After export to the cytoplasm, the precursor of the miRNA (pre-miRNA) containing a stem loop structure, is recognized and cleaved by Dcr-1 (Ha and Kim, 2014; Lee et al., 2004). In the case of Dcr-2, the template is a long dsRNA, which can result from either convergent transcription or the presence of long inverted repeats in a transcript (endo-siRNAs), but also from internalized dsRNAs (exo-siRNAs)(Czech et al., 2008; Kawamura et al., 2008; Marques et al., 2010) or intermediates of replication typically produced during a viral infection (vsiRNAs) (Aliyari et al., 2008; Bronkhorst et al., 2012; Mueller et al., 2010; Sabin et al., 2013; Vodovar et al., 2011). These small RNAs are then loaded onto enzymes of the Argonaute (AGO) family, AGO1 for miRNAs and AGO2 for siRNAs, where one of the strands will be discarded. The remaining strand, known as the guide strand, is used to direct the AGO enzyme towards its target RNA for translation inhibition or degradation, thus achieving silencing of gene expression. The third pathway involves slightly longer small RNAs, the 24-28nt 
111 long PIWI-associated RNAs (piRNAs), which are produced by a Dcr-independent mechanism and associate with a different clade of AGO enzymes, known as PIWI

113 (Saito et al., 2006; Vagin et al., 2006). The drosophila genome encodes three of these,

114 Piwi, AGO3 and Aubergine (Senti and Brennecke, 2010; Siomi et al., 2011).

\subsection{Activation of the siRNA pathway by viral and non viral RNAs}

The multiple lines of evidence supporting a major role in antiviral defense for the siRNA pathway, including (i) the phenotypic characterization of flies mutant for the genes encoding the three core components of the pathway, Dcr-2, r2d2 and AGO2; (ii) the identification of virus-derived siRNAs in infected flies; and (iii) the identification of viral suppressors in several insect viruses, have been reviewed elsewhere (Aguiar et al., 2016; Guo et al., 2019; Nayak et al., 2013; Schuster et al., 2019). The importance of the pressure put by viruses on the siRNA pathway to escape it is probably best illustrated by the viral suppressor of RNAi encoded by the Cricket Paralysis virus (CrPV, Table 1), CrPV-1A. This small viral protein targets AGO2 by two different mechanisms, directly blocking its RNA slicing activity and, at the same time, recruiting 127 cellular proteins to assemble a virus-hijacked E3 ligase to destabilize the enzyme 128 (Nayak et al., 2018; Watanabe et al., 2017). Intriguingly, CrPV-1A can also repress host transcription through a different domain, suggesting that this viral protein may also act as a suppressor of inducible responses (Khong et al., 2017).

Important remaining questions in the field pertain to the mechanism by which Dcr-

1322 recognizes viral RNA and the exact nature of the viral templates that are sensed by 133 the enzyme. Interestingly, it was recently shown that Dcr-2 initiates cleavage of dsRNA 134 differently depending on their extremities. Whereas the platform-PAZ domain 135 recognizes templates with 3 'OH overhang extremities, dsRNA with blunt termini 
engage the N-terminal helicase domain (Sinha et al., 2018). This helicase domain belongs to the superfamily (SF) 2 group of helicases, like the retinoic acid-inducible gene (RIG)-I like receptors in vertebrates, which sense viral RNAs in the cytosol and trigger interferons (IFNs) synthesis. SF2 helicases exhibit three subdomains, Hel1, Hel2i and Hel2, which change conformation upon binding viral RNA, thus triggering signaling (in the case of RIG-I like receptors (Kolakofsky et al., 2012; Kowalinski et al., 2011)) or processive cleavage of dsRNA (in the case of Dcr-2 (Sinha et al., 2018, 2015)). This suggests an ancestral function for the helicase domain of Dcr-2 in antiviral immunity, associated to a role in recognition of non-self RNA. By contrast, the platformPAZ domain, located downstream of the $\mathrm{N}$-terminal helicase domain, may mediate recognition of self RNA and participate in the cellular regulatory functions of Dcr-2 (e.g. endo-siRNA pathway). Small dsRBPs, such as Loquacious (Loqs) and R2D2, play important roles in the modulation of the different activities of Dcr-2 (Cenik et al., 2011; Hansen et al., 2019; Marques et al., 2010; Trettin et al., 2017). These dsRBPs have two or three dsRNA binding motifs, which bind either dsRNA or, following loss of amino-acids important for nucleic acid binding, other proteins to regulate their activity. Interestingly, some of these dsRBPs interact with the helicase domain of Dcr-2 and modulate its functions (Donelick et al., 2020; Hansen et al., 2019). For example, the PD isoform of Loqs is essential for the generation of endo- and exo-siRNAs but dispensable for the production of vsiRNAs (Marques et al., 2013). This observation, confirmed by reconstitution experiments in human cells with drosophila genes (Girardi et al., 2015; Kennedy et al., 2017), reveals that cofactors of the core components Dcr2, R2D2 and AGO2 play important roles in the siRNA pathway. Thus, Dcr-2 may be able to sense viral dsRNAs with blunt termini as non-self through its helicase domain, while requiring loqs-PD for the processing of endo siRNAs. Intriguingly, in Aedes 
161

162

163

164

mosquitoes, which are important vectors for Dengue and other viruses, the Loqs gene has been duplicated and Loqs2, one of the two paralogues, is required for the antiviral siRNA pathway, but dispensable for the endo- and exo-siRNA pathways (Olmo et al., 2018). Overall, these results point to the importance of characterizing the termini of the dsRNAs processed by Dcr-2 in virus infected cells or flies to better understand its function. Identifying the exact role of Loqs and related proteins represents another frontier for the field in the coming years, all the more so because other small dsRBD proteins appear to be involved in RNAi. One of them is Blanks, a testis specific factor, which is required to export dsRNAs from the nucleus to the cytosol, where they can be processed by Dcr-2 (Nitschko et al., 2020). Interestingly, innate immunity genes are upregulated in the testis of blanks mutant flies, pointing to a possible connection between RNAi and other innate immunity pathways (Gerbasi et al., 2011). While Blanks does not seem to participate in antiviral immunity, another related protein, DISCO interacting protein 1 (DIP1), has been proposed to play a role in the control of viral infections although the mechanism remains unknown (Zhang et al., 2015).

Finally, antiviral RNAi in drosophila has also been reported to involve a systemic component, associated with reverse transcription of viral RNA into DNA and production of secondary siRNAs. The characterization of the specific components of systemic RNAi and the mechanisms involved represent an important challenge for the field (Goic et al., 2013; Mondotte et al., 2018; Poirier et al., 2018; Saleh et al., 2009; Tassetto et al., 2017).

2.2. Regulation of gene expression by Dcr-1 and Dcr-2 contributes to virushost interaction in flies 
Although primarily involved in the regulation of cellular gene expression, the miRNA

186

187

188

189

190

191

192

193

194

195

196

197

198

199

200

201

202

203

204

205

206

207

208

pathway is also involved in host-virus interactions in many animals, including flies. For

example, several DNA viruses produce miRNAs that modulate expression of host genes to facilitate dissemination of the virus (reviewed in (Tuddenham and Pfeffer, 2011)). The identification of an abundant miRNA, produced by $\mathrm{KV}$, with up to few hundreds putative targets in the drosophila genome, paves the way to the characterization of this type of regulation in flies (Webster et al., 2015). In addition, some cellular miRNAs have been shown to modulate DCV replication by regulating proviral genes (e.g. miR-8-5p and dJun ((Monsanto-Hearne et al., 2017a)) or antiviral genes (e.g. miR956 and Ect4 ((Monsanto-Hearne et al., 2017b)).

Besides its role in RNA silencing, Dcr-2 also participates in non-canonical cytoplasmic poly-adenylation of a subset of messenger RNAs in drosophila embryos. Of note, at least two immunity related genes, Toll and R2D2, depend on Dcr-2 for their poly-adenylation (Coll et al., 2018). This study suggests that a complex composed of Dcr-2 and Wispy, a cytoplasmic poly $(A)$ polymerase, is necessary for cytoplasmic polyadenylation of these genes. This newly described function of Dcr-2, which affects the translation efficiency of the targeted genes, may help explain other roles of Dcr-2 that seem to be RNAi-independent. These include an involvement of Dcr-2 in resistance to various stresses, such as starvation, cold, but also oxidative or endoplasmic reticulum stresses (Lim et al., 2011). A direct post-transcriptional effect of Dcr-2, involving interaction between the helicase domain and the mRNA, may also regulate the expression of genes associated with host defense, e.g. the single von Willebrand factor-C (SVC) domain proteins like Vago in drosophila, which participate in antiviral immunity in flies, mosquitoes and bumblebees (Asad et al., 2018; Deddouche et al., 
2008; Deng et al., 2020; Harsh et al., 2018; Paradkar et al., 2012; H. Wang et al., 2017).

\subsection{The piRNA pathway and the control of foreign genetic elements}

In drosophila, the piRNA pathway plays a crucial role in the protection of the germline against transposable elements (Brennecke et al., 2007; Pélisson et al., 2007; Senti and Brennecke, 2010). Ten years ago, piRNAs derived from viruses persistently infecting a drosophila cell line derived from ovaries (OSS cells) were reported, raising the possibility that the piRNA pathway participated in antiviral immunity in the germline and possibly also in somatic tissues (Wu et al., 2010). Rapidly, a role for this pathway was also proposed in Aedes mosquitoes, based on expansion of the Piwi family in these insects, some of which are clearly expressed in somatic tissue, and the identification of virus-derived piRNAs first in cell lines but also in mosquitoes for Chikungunya virus (reviewed in (Miesen et al., 2016)). In drosophila, subsequent in vivo experiments ruled out a role for the germline-specific piRNA pathway in antiviral defense, even in ovaries where the piRNA pathway is primarily active (Martins et al., 2019; Petit et al., 2016) and the biological relevance of the initial observation in the OSS cell line remains unclear. Thus, flies appear to be different from mosquitoes regarding a possible role of piRNAs in antiviral immunity. This observation highlights the need to proceed with caution when extrapolating results from drosophila to other insects, as further emphasized below.

A recent pan-arthropod metagenomic analysis revealed that somatic piRNAs targeting transposable elements are common among arthropods, unlike drosophila. The same study suggested that although some viruses may be targeted by somatic piRNAs in mosquitoes, the primary antiviral defense against viruses across arthropod 
234 relies on siRNAs, as observed in flies (Lewis et al., 2018). Of note, the importance of 235 the siRNA pathway in antiviral defense in drosophila and in the nematode 236 Caenorhabditis elegans, two popular laboratory animal models, has led to the assumption that RNAi represented the default antiviral pathway in invertebrates, before the emergence of IFNs in vertebrates (tenOever, 2016). Interestingly, this view has been challenged lately as metagenomic sequencing analysis failed to identify canonical vsiRNAs in most animals belonging to divergent phyla (Porifera, Cnidaria, Echinodermata, Mollusca, and Annelida) (Waldron et al., 2018). Even in drosophila, antiviral resistance mechanisms independent of RNA silencing are emerging in some tissues, e.g. epithelia (Martins et al., 2019; Mondotte et al., 2018; Palmer et al., 2020). Therefore, the prominent role of RNAi in antiviral immunity described for arthropods and nematodes may not be representative of the majority of invertebrates (Waldron et al., 2018).

\section{Inducible responses to virus infection in flies}

The recent discovery of IFN-like induced responses to virus infection in oysters (Lafont et al., 2020; Martins, 2020) and the conservation of the cGAS-STING pathway in the sea anemone Nematostella vectensis (Kranzusch et al., 2015) suggest that ancestral metazoan antiviral immunity involved induced expression of antiviral factors. Virus infection in drosophila is associated with important modifications of the host transcriptome (e.g. Dostert et al., 2005; Kemp et al., 2013; Merkling et al., 2015b; Xu et al., 2012). Some of these modifications reflects the altered physiology of infected flies. For example, DCV infection of the smooth muscle cells surrounding the crop, a food storage organ at the entry of the midgut, results in accumulation of peritrophic 
259 matrix at the entry of the midgut and intestinal obstruction. This alters the physiology of the flies and results in strong repression of a large number of genes associated with digestion (e.g. Jonah proteases) upon DCV infection (Arnold et al., 2013; Chtarbanova et al., 2014). Viral infections are also associated with cellular and tissular stress (e.g. inhibition of cap-dependent translation by internal ribosome entry site (IRES)containing viruses, release of cell debris upon cell lysis, accumulation of unfolded proteins). Such stress can result in gene induction, as suggested by the upregulation of heat-shock proteins upon viral infection (Merkling et al., 2015b). The first pathway reported to be associated with antiviral immunity in flies, the Jak/STAT pathway, highlights the difficulty to dissociate stress responses from bona fide immune 269 mechanisms.

\subsection{The Jak/STAT pathway and antiviral defense in drosophila}

The Janus kinase/signal transducer and activator of transcription (Jak/STAT)

273 signalling pathway is highly conserved in metazoan. In mammals, there are 4 Jak 274 kinases and 7 STAT factors that mediate signalling downstream of receptors for many 275 cytokines, including IFNs (Aaronson and Horvath, 2002). In drosophila, the pathway is 276 composed of a single Jak kinase, Hopscotch (Hop (Hanratty and Dearolf, 1993; 277 Perrimon and Mahowald, 1986)) and a single STAT factor STAT92E (Hou et al., 1996; 278 Yan et al., 1996), acting downstream of the receptor Domeless (Dome), a homologue 279 of the gp130 subunit of the receptors for cytokines of the interleukin-6 family (Brown et 280 al., 2001). The drosophila genome encodes three cytokine-like Unpaired (Upd) 281 proteins, which function as activating ligands for the Dome receptor (Harrison et al., 282 1998; Hombría et al., 2005; Wang et al., 2014). Initially characterized in drosophila for 283 its developmental functions, the Jak/STAT pathway is also involved in tissue 
284 homeostasis in adult flies (reviewed in (Zeidler and Bausek, 2013)). Whereas Upd1 285 appears to function mainly in development, Upd2 and 3 are induced by a number of 286 stresses, including viral infection (Kemp et al., 2013; West and Silverman, 2018; Wright et al., 2011).

Analysis of the transcriptome of DCV-infected flies revealed induction of a number of genes enriched for STAT92E binding sites in their promoter regions. 290 Mutational analysis of the promoter of the highly induced marker gene vir- 1 confirmed 291 that these sites were essential for gene induction (Dostert et al., 2005). Genetic 292 analysis confirmed that vir-1 and a number of other genes are no longer induced by 293 DCV infection in Hop mutant flies. Moreover, these flies are more sensitive to DCV and 294 CrPV infection, although no phenotype was observed for other RNA or DNA viruses 295 (Kemp et al., 2013). These results point to a role for Jak/STAT regulated genes in 296 antiviral response against Dicistroviridae, even if antiviral effectors induced by the 297 pathway have not yet been identified (Dostert et al., 2005b; Kemp et al., 2013, Figure 298 1). In another study, Merkling et al. reported a role for G9a, encoding a histone H3 lysine 9 methyltransferase, in the regulation of the Jak/STAT pathway (Merkling et al., 300 2015a). G9a mutant flies present a shortened lifespan upon infection with the RNA 301 viruses DCV, CrPV, Flock House virus (FHV, Table 1) and Drosophila X virus (DXV, 302 Table 1), which is not associated with increased viral load but rather with an 303 hyperactivation of the Jak/STAT pathway. These results suggest that the epigenetic 304 regulator G9a modulates the activation of the Jak/STAT pathway in response to 305 infection by RNA viruses, in order to prevent deleterious effects caused by 306 hyperactivation (Figure 1). Of note, the authors observed induction of vir-1 and of the 307 stress-induced Turandot genes, TotA and TotM (Ekengren et al., 2001), 24h after DCV, 308 CrPV, DXV and FHV infections. In contrast, Kemp and collaborators did not detect 
309 induction of vir-1 upon DXV infection and only observed upregulation of Tot genes a

310 few days after DCV infection, when the flies were starting to die (Kemp et al., 2013).

311 These discrepancies may be explained by differences in the genetic background of the

312 flies used, which could affect induction patterns of the Turandot and vir-1 genes 313 depending on the virus used for the infection, or environmental conditions of infection 314 (e.g. dose of virus, fly media, microbiota).

The role of the Jak/STAT pathway is not limited to the response against RNA viruses, as it also controls the DNA virus Invertebrate iridescent virus (IIV)-6 (Table 1). IIV-6 infection significantly decreases the lifespan of STAT92E silenced flies (West and Silverman, 2018). Using S2 cells and flies carrying Upd hypomorphic alleles, these authors further demonstrated that IIV-6 infection induces expression of the three Upd proteins, which function redundantly to activate the Jak/STAT pathway. In these circumstances, the induction of the cytokines relies on the MAP-kinase p38b, one of 322 the three drosophila p38 homologs. Accordingly, p38b mutant flies succumb more 323 rapidly to IIV-6 infection than controls. West and Silverman further showed that 324 induction of Upd expression required the NADPH oxidase NOX, suggesting that 325 reactive oxygen species (ROS) production, resulting from the viral infection, was 326 triggering activation of $\mathrm{p} 38 \mathrm{~b}$. Of note, $\alpha$-actinin, a component of the cortical 327 cytoskeleton, which can be released upon tissue injury, was also shown to induce 328 Upd3 in a NOX-dependent manner leading to the activation of the Jak/STAT pathway 329 (Gordon et al., 2018; Srinivasan et al., 2016). Notably, signalling to Upd3 induction 330 involved Shark and Src42A, the drosophila homologues of the mammalian Tyrosine 331 kinases Syk and Src, which mediate induction of inflammation and adaptative immunity 332 upon sensing actin, another cortical component of the cytoskeleton. Altogether, these 333 data suggest that release of $\alpha$-actinin upon IIV-6 triggered cell death induces 
production of Upd cytokines, leading to the activation of the Jak/STAT pathway (Figure

335 1).

In summary, the Jak/STAT pathway seems to be induced primarily as a result of cell damage caused by viral infection, rather than by directly sensing viral molecular patterns in drosophila. In addition, this pathway appears to primarily increase resilience to infection, rather than resistance, as mutant flies exhibit increased lethality, with little or no impact on viral titres (Merkling et al., 2015a; West and Silverman, 2018). Alternatively, the viruses tested may have evolved suppressor mechanisms opposing antiviral effectors induced by the Jak/STAT pathway. In this regard, it is interesting to note that infection of $\mathrm{S} 2$ cells by the newly discovered DNA virus KV resulted in downregulation of a reporter gene driven by a synthetic promoter composed of 10 STAT-binding sites (Palmer et al., 2019). This suggests that KV encodes a suppressor, the characterization of which would provide strong evidence for the importance of the Jak/STAT pathway in antiviral immunity in flies.

\subsection{Control of viral infections by the Toll pathway}

Two distinct pathways, Toll and IMD, rely on NF-кB transcription factors to regulate expression of AMPs genes in drosophila ((Buchon et al., 2014) and references therein). Toll regulates Dorsal (DI) and Dorsal-related immunity factor (DIF), whereas IMD controls the third member of the family in drosophila, Relish. These pathways have well established roles in the control of bacterial and fungal infections but involvement in antiviral defence has also been suggested (Figure 1).

A comprehensive study by Teixeira and collaborators reported the involvement of the Toll pathway in the defence against a broad range of RNA viruses (DCV, CrPV, FHV, Nora virus (Table 1)(Ferreira et al., 2014)). Interestingly, the authors observed 
359

360

361

362

that the Toll pathway is important to survive oral infection but not systemic infection by these viruses, even though activation of the Toll pathway is detected in the fat body following both types of infection. This emphasizes the importance of the route of infection for host-pathogen interaction (Martins et al., 2013). Furthermore, the data suggest that the Toll pathway is targeting a step of the viral cycle occurring specifically in the course of oral infection and bypassed by an injection directly in the hemocoel (Ferreira et al., 2014). Of note, in addition to spaetzle, Toll and pelle, dorsal mutants presented an increased susceptibility to oral infection while Dif mutant did not. These results suggest that, while DIF mediates the Toll-dependent response triggered by bacteria and fungi infection (Rutschmann et al., 2000), DI is responsible for antiviral defences (Ferreira et al., 2014), providing an explanation for the long-noted expression of DI in the fat body of adult flies (Lemaitre et al., 1995).

Obbard and colleagues did not observe increased sensitivity of Toll pathway mutant flies to infection with the DNA virus $\mathrm{KV}$, which may be explained by the fact that they did not use an oral infection model. However, they reported a strong suppression of Toll pathway activity in KV infected flies (Palmer et al., 2019). They further identified a previously uncharacterized KV gene, gp83, which encodes a potent suppressor of Toll signalling (Figure 1). The mode of action of this nuclear protein, which appears to act downstream of DIF or DI, is still mysterious. Whatever the mechanism, identification of a viral suppressor provides further evidence for a role of the Toll pathway in antiviral immunity.

80 Overall, these findings raise the question of the mechanism by which viral infection may activate the Toll pathway. One possibility is that tissue damage and necrosis caused by viral infection may result in activation of the Toll pathway through activation of the Persephone (psh) protease (Figure 1 (Ming et al., 2014; Tang et al., 
2008)). Another important question pertains to the induction of an antiviral versus antifungal response by the Toll pathway. While it could be argued that DIF and DI may regulate antifungal and antiviral effector genes, respectively, it is intriguing that some reports suggest an involvement of DIF, rather than DI, in antiviral immunity, independently of the canonical Toll pathway. Indeed, dif, but not $s p z$, tll, tube and pelle, mutant flies were reported to exhibit increased sensitivity to DXV (Zambon et al., 2005). Although the genetic background was not controlled in these early experiments, it is intriguing that induction of the cytokine Diedel (Die) following Sindbis virus (SINV, Table 1) infection depends on DIF but not MyD88, which is the adaptor of the canonical Toll pathway (Lamiable et al., 2016b, Figure 1). Finally, a recent report points to the activation of a non-canonical pathway leading to expression of two Toll-regulated AMPs, drosomycin and attacin-A in response to DCV infection (Zhang et al., 2020). This highlights the importance of further investigations on the role of the Toll pathway in antiviral immunity, and on the respective contributions of DIF and DI in the expression of genes involved in antiviral defenses.

\subsection{Relish-dependent antiviral immunity}

A role of the IMD pathway in the resistance to CrPV and SINV was first reported in 2009 (Avadhanula et al., 2009; Costa et al., 2009), followed a few years later by the description of antiviral activity for two antimicrobial peptides, Diptericin-B and AttacinC (Huang et al., 2013). It is interesting to note that, besides its role in the expression of antibacterial peptides, the IMD pathway is also implicated in the regulation of apoptosis (Georgel et al., 2001; Tavignot et al., 2017; Zhai et al., 2018). Indeed, programmed cell death represents an efficient antiviral defense, interrupting viral replication (Liu et al., 2013). Efficient phagocytosis of apoptotic cells further prevents 
dissemination of viruses (Lamiable et al., 2016a; Nainu et al., 2015). In drosophila,

410 apoptosis is largely controlled at the level of the inhibitory protein DIAP1, which

411 prevents activation of caspases. The IMD pathway may regulate apoptosis in the

412 context of viral infection by triggering DIAP1 protein degradation via DIAP2-mediated

413 polyubiquitination (Herman-Bachinsky et al., 2007). However, the situation is likely to

414 be more complex as IMD signalling antagonizes apoptosis in some tissues during

415 development by upregulating DIAP1 gene transcription (Tavignot et al., 2017). Of note,

416 DCV was shown to suppress the N-end rule pathway, one of the mechanisms causing

417 DIAP1 degradation. This enables the virus to block or slow down programmed cell

418 death resulting in enhanced replication (Wang Z. et al., 2017).

Characterization of the virus-induced gene Die confirmed a role of the IMD

420 pathway in antiviral immunity (Lamiable et al., 2016b). Indeed, Die mutant flies were

421 more sensitive to infection with SINV than controls and early lethality was not

422 accompanied by increased viral titer but rather correlated with strong upregulation of

423 IMD target genes. Flies double mutant for Die and IMD or $i k k \gamma$ resisted like wild-type

424 flies to SINV infection, confirming that it was the overactivation of the IMD pathway,

425 rather than the lack of Die per se, that caused the demise of the flies. Die encodes a

426 small circulating protein that probably functions as an immunomodulatory cytokine

427 downregulating the IMD pathway by an unknown mechanism (Lamiable et al., 2016b).

428 Intriguingly, this cytokine also appears to inhibit apoptosis in developmental contexts

429 (Mlih et al., 2018). Die-related genes can be found in the genomes of DNA viruses

430 belonging to at least three families (Ascoviridae, Entomopoxviridae, Baculoviridae,

431 Figure 1), and at least one of them can rescue the phenotype of Die-mutant flies

432 (Lamiable et al., 2016b). This result indicates that insect viruses have, on several

433 occasions, hijacked a suppressor gene of the IMD pathway, suggesting that activation 
434 of this pathway during infection exerts a pressure on viruses. Interestingly, IIV-6 does 435 not encode a Die homologue but expresses another as yet poorly characterized 436 suppressor of IMD signalling, acting in the nucleus at the level of Relish-mediated 437 transcriptional activation (West et al., 2019).

$438 \quad$ Together with previous results reporting inhibition of $N F-\kappa B$ signalling by 439 vankyrin proteins encoded by polydnaviruses (Gueguen et al., 2013), these recent 440 findings prompted a careful examination of the role of the IMD pathway in the control 441 of viral infection in the S2 cell line. This revealed that silencing of IKK $\beta$ and Relish 442 resulted in significantly increased replication of DCV. Unexpectedly, silencing of the 443 other genes of the IMD pathway did not affect viral load, with the exception of $444 \mathrm{IKK} \gamma / \mathrm{NEMO}$, the regulatory subunit of the IKK complex, for which viral replication was 445 decreased (Goto et al., 2018). This suggested that downstream components of the pathway could be activated independently of IMD in response to a viral infection. One of the genes induced by DCV infection in an IKK $\beta$ and Relish-dependent manner is the 448 homologue of the gene STING (stimulator of interferon genes). In mammals, STING is 449 a key component of the cytosolic DNA sensing system, activating IFN genes in 450 response to a second messenger, the cyclic dinucleotide (CDN) 2'3'-cyclic GMP-AMP 451 (2'3'-cGAMP). This CDN contains one 2',5' phosphodiester bond joining $G$ to $A$ and 452 one canonical 3', 5'-phosphodiester bond joining A to G. It is produced by the enzyme 453 cyclic GMP-AMP synthase (cGAS), which becomes activated upon binding DNA or 454 DNA/RNA duplexes in the cytosol (reviewed in (Ablasser and Chen, 2019)). Of note, STING can also be activated by CDNs of bacterial origin, which contain two canonical 3',5' phosphodiester-linkages (3'3'-cGAMP, c-di-GMP, c-di-AMP (Margolis et al., 457 2017)). In drosophila cells, ectopic expression of dSTING can prevent replication of 458 DCV in an IKK $\beta$ - and Relish-dependent manner, suggesting that dSTING acts 
459 upstream of these two proteins in a new pathway activated by viral infections (Goto et 460 al., 2018). Interestingly, similar results were reported in Bombyx mori, where a 461 homologue of STING activates Relish and antiviral immunity in response to infection 462 by nucleopolyhedrovirus (NPV (Hua et al., 2018)). Altogether, these results suggest 463 that an ancestral function of the evolutionarily ancient molecule STING is the regulation 464 of NF-kB-dependent transcription of antiviral genes, predating the appearance of IFNs 465 (Figure 1). Of note, activation of Relish by the IMD pathway in response to bacterial 466 infections requires both its phosphorylation by $\mathrm{IKK} \beta$ and its cleavage by the caspase DREDD in a process that involves the IKK $\gamma / \mathrm{NEMO}$ protein (reviewed in (Buchon et al., 2014)). By contrast, activation of Relish by dSTING does not appear to require DREDD and is opposed by IKK $\gamma /$ NEMO (Goto et al., 2018).

It is noteworthy that an IMD-independent function of Relish has previously been

471 described in salivary gland degradation during metamorphosis (Nandy et al., 2018).

472 Thus, besides the IMD pathway, Relish can be regulated by non-classical pathways 473 and activate transcriptional outputs distinct from the IMD pathway, probably in 474 association with specific transcription cofactors (Zhai et al., 2018). Interestingly, Relish 475 regulates expression of the gene Atg1 in salivary glands to trigger autophagy476 dependent cell death. This may provide a connection with the role of dSTING in 477 antiviral immunity. Indeed, in mammals, besides expression of IFNs, STING also 478 regulates autophagy, which is thought to represent an ancestral antiviral function (Gui 479 et al., 2019; Margolis et al., 2017). Similarly, dSTING was reported to induce 480 autophagy in the drosophila brain to control ZIKA virus replication (Liu et al., 2018). A major question at this point pertains to the activation of Relish in virus-infected 482 flies. In the absence of bacterial infection, the IMD pathway may be activated by a 483 response to necrotic cells possibly driven by dysbiosis (Kosakamoto et al., 2020) or by 
484 deregulation of the expression of the receptors PGRP-LC or -LF (Nandy et al., 2018;

485 Tavignot et al., 2017). The involvement of dSTING in the regulation of Relish activity 486 in the context of viral infections now raises the question of the mechanisms by which

487 it gets activated. The drosophila genome encodes one obvious cGAS homologue, 488 CG7194, which does not seem to participate in antimicrobial defenses (Martin et al., 489 2018; Wu et al., 2014). This led Goodman and colleagues to propose that in 490 drosophila, dSTING is activated by bacterial CDNs, rather than the host-produced 491 second messenger 2'3'-cGAMP. However, we recently observed that 2'3'-cGAMP is a 492 more potent activator of STING-regulated genes in drosophila than 3'3'-linked bacterial 493 CDNs (Cai et al., 2020). This suggests that a cGAS-like enzyme might exist in 494 drosophila, as already reported in the sea anemone Nematostella vectensis 495 (Kranzusch et al., 2015) and in the Lepidopteran insect B. mori (Hua et al., 2018).

\section{Concluding remarks}

498

Recent work in the field of drosophila antiviral immunity, while improving our 500 understanding on the contribution of small regulatory RNAs, have provided increasing evidence that induced immune responses, and in particular NF- $\kappa$ B pathways, also play an important role. Interestingly, inducible antiviral immune responses appear to play 503 an important role in other invertebrates as well (e.g. (Lafont et al., 2017)). While initial 504 studies suggested that invertebrates primarily relied on ancestral RNAi response to 505 control viruses, which was replaced by IFN-regulated inducible responses in vertebrates, a more complex picture is now emerging. In particular, it is now clear that 507 inducible antiviral immune responses predate the appearance of IFNs in vertebrates, 508 and that some antiviral genes (e.g. cGAS, viperin, STING) were inherited from 
509 procaryotes (Bernheim et al., 2020; Cohen et al., 2019; Morehouse et al., 2020; Sen

510

511 and Peters, 2007). Of note, important differences among insects are also becoming apparent (e.g. presence of virus-derived piRNAs in mosquitoes but not in drosophila; absence of the STING gene in mosquitoes). These differences are not surprising in light of the strong pressures exerted on host genomes by rapidly mutating viruses. Documenting these differences and their analysis can reveal important information on the mechanisms at play in the arms race between viruses and the immune system of their hosts (Daugherty and Malik, 2012). In summary, while D. melanogaster will continue to be an invaluable tool in future work to decipher the complex host-virus interactions (e.g. molecular mechanisms of pathogenesis (Chow et al., 2017)), caution should be exerted before extrapolating findings in this model to other insects, all the more so to invertebrates in general.

The basic mechanisms involved in the restriction of viruses by the siRNA pathway in drosophila have now been well characterized, although key questions remain. Among them, the question of the sensing of viral RNAs is central, as it is now clear that there is more to it than the double strandedness of replication intermediates, for example. Future work will need to determine if the discrimination between viral and self RNAs involves the quantity of template for Dcr-2, differences at the extremities of the RNAs or their subcellular localization, all of which contribute to the activation of nucleic acid sensing pattern recognition receptors (PRRs) in mammalian cells (Roers et al., 2016). Clarification of the role of dsRBPs cofactors represents another priority for the field, together with the elucidation of the mechanism by which an intrinsically cell autonomous process (Roignant et al., 2003) can generate a systemic response in the context of viral infections (Saleh et al., 2009; Tassetto et al., 2017). 
534 work relates to the identification of the receptors sensing viral infections, in particular 535 whether these responses involve bona fide PRRs, and in this case what types of 536 molecular patterns are recognized. The field will also greatly benefit from the 537 investigation of the modes of action of viral suppressors of inducible responses, which 538 could reveal new regulatory facets of inducible immunity pathways. The interplay of 539 the IMD- and dSTING-dependent Relish functions in response to bacterial and viral 540 infections, respectively, also deserves attention, as highlighted by the contribution of 541 the microbiota to antiviral immunity (Sansone et al., 2015; Teixeira et al., 2008; Xu et 542 al., 2013). Last but not least, a major unsolved question is the function of the many 543 induced genes, which contribute to the control of viral infections. Indeed, the functional 544 characterization of new antiviral factors could reveal original targets for the design of 545 therapy against families of viruses infecting both insects and mammals, such as 546 picorna-like viruses, alphaviruses, rhabdoviruses or poxviruses (Shi et al., 2016).

\section{Ackowledgements}

549 We thank our colleagues Joao T. Marques and Nelson Martins for critical reading of 550 the manuscript and helpful suggestions. Work in our laboratory is supported by CNRS, 551 the Investissements d'avenir program (Labex NetRNA: ANR-10- LABX-0036; Equipex 552 I2MC: ANR-11-EQPX-0022) and ANR (ANR-17-CE15-0014). JS is supported by a 553 fellowship from the Ministère de I'Enseignement supérieur, de la Recherche et de 554 I'Innovation and JLI acknowledges financial support from the Institut Universitaire de 555 France. 
559

560

561

562

563

564

565

566

567

568

569

570

571

572

573

574

575

576

577

578

579

580

581

582

583

584

585

586

587

588

589

590

591

592

593

594

595

596

597

598

599

600

601

602

603

604

Aaronson, D.S., Horvath, C.M., 2002. A road map for those who don't know JAK-STAT. Science 296, 1653-1655. https://doi.org/10.1126/science.1071545

Ablasser, A., Chen, Z.J., 2019. cGAS in action: Expanding roles in immunity and inflammation. Science 363. https://doi.org/10.1126/science.aat8657

Aguiar, E.R.G.R., Olmo, R.P., Marques, J.T., 2016. Virus-derived small RNAs: molecular footprints of host-pathogen interactions. Wiley Interdiscip Rev RNA 7, 824-837. https://doi.org/10.1002/wrna.1361

Aliyari, R., Wu, Q., Li, H.-W., Wang, X.-H., Li, F., Green, L.D., Han, C.S., Li, W.-X., Ding, S.-W., 2008. Mechanism of induction and suppression of antiviral immunity directed by virus-derived small RNAs in Drosophila. Cell Host Microbe 4, 387-397. https://doi.org/10.1016/j.chom.2008.09.001

Arnold, P.A., Johnson, K.N., White, C.R., 2013. Physiological and metabolic consequences of viral infection in Drosophila melanogaster. J Exp Biol 216, 3350-3357. https://doi.org/10.1242/jeb.088138

Asad, S., Parry, R., Asgari, S., 2018. Upregulation of Aedes aegypti Vagol by Wolbachia and its effect on dengue virus replication. Insect Biochem. Mol. Biol. 92, 45-52. https://doi.org/10.1016/j.ibmb.2017.11.008

Avadhanula, V., Weasner, B.P., Hardy, G.G., Kumar, J.P., Hardy, R.W., 2009. A novel system for the launch of alphavirus RNA synthesis reveals a role for the Imd pathway in arthropod antiviral response. PLoS Pathog. 5, e1000582. https://doi.org/10.1371/journal.ppat.1000582

Bernheim, A., Millman, A., Ofir, G., Meitav, G., Avraham, C., Shomar, H., Rosenberg, M.M., Tal, N., Melamed, S., Amitai, G., Sorek, R., 2020. Prokaryotic viperins produce diverse antiviral molecules. Nature. https://doi.org/10.1038/s41586-020-2762-2

Brennecke, J., Aravin, A.A., Stark, A., Dus, M., Kellis, M., Sachidanandam, R., Hannon, G.J., 2007. Discrete small RNA-generating loci as master regulators of transposon activity in Drosophila. Cell 128, 1089-1103. https://doi.org/10.1016/j.cell.2007.01.043

Bronkhorst, A.W., van Cleef, K.W.R., Vodovar, N., Ince, I.A., Blanc, H., Vlak, J.M., Saleh, M.-C., van Rij, R.P., 2012. The DNA virus Invertebrate iridescent virus 6 is a target of the Drosophila RNAi machinery. Proc. Natl. Acad. Sci. U.S.A. 109, E3604-3613. https://doi.org/10.1073/pnas.1207213109

Brown, S., Hu, N., Hombría, J.C., 2001. Identification of the first invertebrate interleukin JAK/STAT receptor, the Drosophila gene domeless. Curr Biol 11, 1700-1705. https://doi.org/10.1016/s0960-9822(01)00524-3

Buchon, N., Silverman, N., Cherry, S., 2014. Immunity in Drosophila melanogaster--from microbial recognition to whole-organism physiology. Nature Reviews. Immunology 14, 796-810. https://doi.org/10.1038/nri3763

Cai, H., Holleufer, A., Simonsen, B., Schneider, J., Lemoine, A., Gad, H.H., Huang, Jingxian, Huang, Jieqing, Chen, D., Peng, T., Marques, J.T., Hartmann, R., Martins, N.E., Imler,

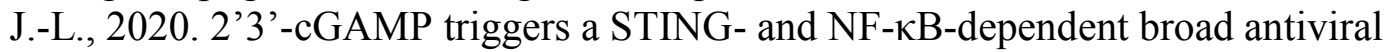
response in Drosophila. Sci Signal 13. https://doi.org/10.1126/scisignal.abc4537

Cao, C., Cogni, R., Barbier, V., Jiggins, F.M., 2017. Complex Coding and Regulatory Polymorphisms in a Restriction Factor Determine the Susceptibility of Drosophila to Viral Infection. Genetics 206, 2159-2173. https://doi.org/10.1534/genetics. 117.201970

Cao, C., Magwire, M.M., Bayer, F., Jiggins, F.M., 2016. A Polymorphism in the Processing Body Component Ge-1 Controls Resistance to a Naturally Occurring Rhabdovirus in 

2011. Phosphate and R2D2 Restrict the Substrate Specificity of Dicer-2, an ATP-Driven Ribonuclease. Molecular Cell 42, 172-184. https://doi.org/10.1016/j.molcel.2011.03.002

609

610

611

612

613

614

615

616

617

618

619

620

621

622

623

624

625

626

627

628

629

630

631

632

633

634

635

636

637

638

639

640

641

642

643

644

645

646

647

648

649

650

651

652

653

654

Chow, J., Kagan, J.C., 2018. Chapter Three - The Fly Way of Antiviral Resistance and Disease Tolerance, in: Alt, F. (Ed.), Advances in Immunology. Academic Press, pp. 5993. https://doi.org/10.1016/bs.ai.2018.08.002

Chow, J., Márka, Z., Bartos, I., Márka, S., Kagan, J.C., 2017. Environmental Stress Causes Lethal Neuro-Trauma during Asymptomatic Viral Infections. Cell Host Microbe 22, 4860.e5. https://doi.org/10.1016/j.chom.2017.06.010

Chtarbanova, S., Lamiable, O., Lee, K.-Z., Galiana, D., Troxler, L., Meignin, C., Hetru, C., Hoffmann, J.A., Daeffler, L., Imler, J.-L., 2014. Drosophila C virus systemic infection leads to intestinal obstruction. J. Virol. 88, 14057-14069.

https://doi.org/10.1128/JVI.02320-14

Cohen, D., Melamed, S., Millman, A., Shulman, G., Oppenheimer-Shaanan, Y., Kacen, A., Doron, S., Amitai, G., Sorek, R., 2019. Cyclic GMP-AMP signalling protects bacteria against viral infection. Nature 574, 691-695. https://doi.org/10.1038/s41586-019-1605-5

Coll, O., Guitart, T., Villalba, A., Papin, C., Simonelig, M., Gebauer, F., 2018. Dicer-2 promotes mRNA activation through cytoplasmic polyadenylation. RNA 24, 529-539. https://doi.org/10.1261/rna.065417.117

Costa, A., Jan, E., Sarnow, P., Schneider, D., 2009. The Imd pathway is involved in antiviral immune responses in Drosophila. PLoS ONE 4, e7436.

https://doi.org/10.1371/journal.pone.0007436

Czech, B., Malone, C.D., Zhou, R., Stark, A., Schlingeheyde, C., Dus, M., Perrimon, N., Kellis, M., Wohlschlegel, J.A., Sachidanandam, R., Hannon, G.J., Brennecke, J., 2008. An endogenous small interfering RNA pathway in Drosophila. Nature 453, 798-802. https://doi.org/10.1038/nature07007

Daugherty, M.D., Malik, H.S., 2012. Rules of engagement: molecular insights from hostvirus arms races. Annu. Rev. Genet. 46, 677-700. https://doi.org/10.1146/annurev-genet110711-155522

Deddouche, S., Matt, N., Budd, A., Mueller, S., Kemp, C., Galiana-Arnoux, D., Dostert, C., Antoniewski, C., Hoffmann, J.A., Imler, J.-L., 2008. The DExD/H-box helicase Dicer-2 mediates the induction of antiviral activity in drosophila. Nat. Immunol. 9, 1425-1432. https://doi.org/10.1038/ni.1664

Deng, P., Khan, A., Jacobson, D., Sambrani, N., McGurk, L., Li, X., Jayasree, A., Hejatko, J., Shohat-Ophir, G., O’Connell, M.A., Li, J.B., Keegan, L.P., 2020. Adar RNA editingdependent and -independent effects are required for brain and innate immune functions in Drosophila. Nat Commun 11, 1580. https://doi.org/10.1038/s41467-020-15435-1

Donelick, H.M., Talide, L., Bellet, M., Aruscavage, J., Lauret, E., Aguiar, E., Marques, J.T., Meignin, C., Bass, B.L., 2020. In vitro studies provide insight into effects of Dicer-2 helicase mutations in Drosophila melanogaster. RNA.

https://doi.org/10.1261/rna.077289.120

Dostert, C., Jouanguy, E., Irving, P., Troxler, L., Galiana-Arnoux, D., Hetru, C., Hoffmann, J.A., Imler, J.-L., 2005a. The Jak-STAT signaling pathway is required but not sufficient for the antiviral response of drosophila. Nat. Immunol. 6, 946-953. https://doi.org/10.1038/ni1237

Dostert, C., Jouanguy, E., Irving, P., Troxler, L., Galiana-Arnoux, D., Hetru, C., Hoffmann, J.A., Imler, J.-L., 2005b. The Jak-STAT signaling pathway is required but not sufficient for the antiviral response of drosophila. Nat. Immunol. 6, 946-953. https://doi.org/10.1038/ni1237 
Ekengren, S., Tryselius, Y., Dushay, M.S., Liu, G., Steiner, H., Hultmark, D., 2001. A humoral stress response in Drosophila. Curr Biol 11, 714-718. https://doi.org/10.1016/s0960-9822(01)00203-2

Eleftherianos, I., Won, S., Chtarbanova, S., Squiban, B., Ocorr, K., Bodmer, R., Beutler, B., Hoffmann, J.A., Imler, J.-L., 2011. ATP-sensitive potassium channel (K(ATP))dependent regulation of cardiotropic viral infections. Proc. Natl. Acad. Sci. U.S.A. 108, 12024-12029. https://doi.org/10.1073/pnas.1108926108

Ferreira, Á.G., Naylor, H., Esteves, S.S., Pais, I.S., Martins, N.E., Teixeira, L., 2014. The Toll-dorsal pathway is required for resistance to viral oral infection in Drosophila. PLoS Pathog. 10, e1004507. https://doi.org/10.1371/journal.ppat.1004507

Galiana-Arnoux, D., Dostert, C., Schneemann, A., Hoffmann, J.A., Imler, J.-L., 2006. Essential function in vivo for Dicer-2 in host defense against RNA viruses in drosophila. Nat. Immunol. 7, 590-597. https://doi.org/10.1038/ni1335

Gay, P., 1978. [Drosophila genes which intervene in multiplication of sigma virus (author's transl)]. Mol. Gen. Genet. 159, 269-283. https://doi.org/10.1007/BF00268263

Georgel, P., Naitza, S., Kappler, C., Ferrandon, D., Zachary, D., Swimmer, C., Kopczynski, C., Duyk, G., Reichhart, J.M., Hoffmann, J.A., 2001. Drosophila immune deficiency (IMD) is a death domain protein that activates antibacterial defense and can promote apoptosis. Dev Cell 1, 503-514. https://doi.org/10.1016/s1534-5807(01)00059-4

Gerbasi, V.R., Preall, J.B., Golden, D.E., Powell, D.W., Cummins, T.D., Sontheimer, E.J., 2011. Blanks, a nuclear siRNA/dsRNA-binding complex component, is required for Drosophila spermiogenesis. Proc Natl Acad Sci U S A 108, 3204-3209. https://doi.org/10.1073/pnas.1009781108

Ghildiyal, M., Zamore, P.D., 2009. Small silencing RNAs: an expanding universe. Nat Rev Genet 10, 94-108. https://doi.org/10.1038/nrg2504

Girardi, E., Lefèvre, M., Chane-Woon-Ming, B., Paro, S., Claydon, B., Imler, J.-L., Meignin, C., Pfeffer, S., 2015. Cross-species comparative analysis of Dicer proteins during Sindbis virus infection. Sci Rep 5, 10693. https://doi.org/10.1038/srep10693

Goic, B., Vodovar, N., Mondotte, J.A., Monot, C., Frangeul, L., Blanc, H., Gausson, V., Vera-Otarola, J., Cristofari, G., Saleh, M.-C., 2013. RNA-mediated interference and reverse transcription control the persistence of RNA viruses in the insect model Drosophila. Nat. Immunol. 14, 396-403. https://doi.org/10.1038/ni.2542

Gold, K.S., Brückner, K., 2015. Macrophages and cellular immunity in Drosophila melanogaster. Semin. Immunol. 27, 357-368. https://doi.org/10.1016/j.smim.2016.03.010

Gordon, O., Henry, C.M., Srinivasan, N., Ahrens, S., Franz, A., Deddouche, S., Chakravarty, P., Phillips, D., George, R., Kjaer, S., Frith, D., Snijders, A.P., Valente, R.S., Simoes da Silva, C.J., Teixeira, L., Thompson, B., Dionne, M.S., Wood, W., Reis E Sousa, C., 2018. $\alpha$-actinin accounts for the bioactivity of actin preparations in inducing STAT target genes in Drosophila melanogaster. Elife 7. https://doi.org/10.7554/eLife.38636

Goto, A., Okado, K., Martins, N., Cai, H., Barbier, V., Lamiable, O., Troxler, L., Santiago, E., Kuhn, L., Paik, D., Silverman, N., Holleufer, A., Hartmann, R., Liu, J., Peng, T., Hoffmann, J.A., Meignin, C., Daeffler, L., Imler, J.-L., 2018. The Kinase IKK $\beta$ Regulates a STING- and NF- $\kappa B-D e p e n d e n t$ Antiviral Response Pathway in Drosophila. Immunity 49, 225-234.e4. https://doi.org/10.1016/j.immuni.2018.07.013

Gueguen, G., Kalamarz, M.E., Ramroop, J., Uribe, J., Govind, S., 2013. Polydnaviral ankyrin proteins aid parasitic wasp survival by coordinate and selective inhibition of hematopoietic and immune NF-kappa B signaling in insect hosts. PLoS Pathog. 9, e1003580. https://doi.org/10.1371/journal.ppat.1003580

Gui, X., Yang, H., Li, T., Tan, X., Shi, P., Li, M., Du, F., Chen, Z.J., 2019. Autophagy 
induction via STING trafficking is a primordial function of the cGAS pathway. Nature 567, 262-266. https://doi.org/10.1038/s41586-019-1006-9

Guo, Z., Li, Y., Ding, S.-W., 2019. Small RNA-based antimicrobial immunity. Nat. Rev. Immunol. 19, 31-44. https://doi.org/10.1038/s41577-018-0071-X

Ha, M., Kim, V.N., 2014. Regulation of microRNA biogenesis. Nat Rev Mol Cell Biol 15, 509-524. https://doi.org/10.1038/nrm3838

Hanratty, W.P., Dearolf, C.R., 1993. The Drosophila Tumorous-lethal hematopoietic oncogene is a dominant mutation in the hopscotch locus. Mol Gen Genet 238, 33-37. https://doi.org/10.1007/BF00279527

Hansen, S.R., Aderounmu, A.M., Donelick, H.M., Bass, B.L., 2019. Dicer's Helicase Domain: A Meeting Place for Regulatory Proteins. Cold Spring Harb. Symp. Quant. Biol. 84, 185-193. https://doi.org/10.1101/sqb.2019.84.039750

Harrison, D.A., McCoon, P.E., Binari, R., Gilman, M., Perrimon, N., 1998. Drosophila unpaired encodes a secreted protein that activates the JAK signaling pathway. Genes Dev 12, 3252-3263. https://doi.org/10.1101/gad.12.20.3252

Harsh, S., Ozakman, Y., Kitchen, S.M., Paquin-Proulx, D., Nixon, D.F., Eleftherianos, I., 2018. Dicer-2 Regulates Resistance and Maintains Homeostasis against Zika Virus Infection in Drosophila. J. Immunol. 201, 3058-3072. https://doi.org/10.4049/jimmunol.1800597

Herman-Bachinsky, Y., Ryoo, H.-D., Ciechanover, A., Gonen, H., 2007. Regulation of the Drosophila ubiquitin ligase DIAP1 is mediated via several distinct ubiquitin system pathways. Cell Death Differ 14, 861-871. https://doi.org/10.1038/sj.cdd.4402079

Hoffmann, J.A., Kafatos, F.C., Janeway, C.A., Ezekowitz, R.A., 1999. Phylogenetic perspectives in innate immunity. Science 284, 1313-1318.

Hombría, J.C.-G., Brown, S., Häder, S., Zeidler, M.P., 2005. Characterisation of Upd2, a Drosophila JAK/STAT pathway ligand. Dev Biol 288, 420-433. https://doi.org/10.1016/j.ydbio.2005.09.040

Hou, X.S., Melnick, M.B., Perrimon, N., 1996. Marelle acts downstream of the Drosophila HOP/JAK kinase and encodes a protein similar to the mammalian STATs. Cell 84, 411419. https://doi.org/10.1016/s0092-8674(00)81286-6

Hua, X., Li, B., Song, L., Hu, C., Li, X., Wang, D., Xiong, Y., Zhao, P., He, H., Xia, Q., Wang, F., 2018. Stimulator of interferon genes (STING) provides insect antiviral immunity by promoting Dredd caspase-mediated NF- $\kappa B$ activation. J. Biol. Chem. 293, 11878-11890. https://doi.org/10.1074/jbc.RA117.000194

Huang, Z., Kingsolver, M.B., Avadhanula, V., Hardy, R.W., 2013. An antiviral role for antimicrobial peptides during the arthropod response to alphavirus replication. J. Virol. 87, 4272-4280. https://doi.org/10.1128/JVI.03360-12

Hultmark, D., 2003. Drosophila immunity: paths and patterns. Current Opinion in Immunology 15, 12-19. https://doi.org/10.1016/S0952-7915(02)00005-5

Jousset, F.X., Plus, N., Croizier, G., Thomas, M., 1972. [Existence in Drosophila of 2 groups of picornavirus with different biological and serological properties]. C.R. Hebd. Seances Acad. Sci., Ser. D, Sci. Nat. 275, 3043-3046.

Kawamura, Y., Saito, K., Kin, T., Ono, Y., Asai, K., Sunohara, T., Okada, T.N., Siomi, M.C., Siomi, H., 2008. Drosophila endogenous small RNAs bind to Argonaute 2 in somatic cells. Nature 453, 793-797. https://doi.org/10.1038/nature06938

Kemp, C., Mueller, S., Goto, A., Barbier, V., Paro, S., Bonnay, F., Dostert, C., Troxler, L., Hetru, C., Meignin, C., Pfeffer, S., Hoffmann, J.A., Imler, J.-L., 2013. Broad RNA interference-mediated antiviral immunity and virus-specific inducible responses in Drosophila. J. Immunol. 190, 650-658. https://doi.org/10.4049/jimmunol.1102486 Kennedy, E.M., Kornepati, A.V.R., Bogerd, H.P., Cullen, B.R., 2017. Partial reconstitution of 
the RNAi response in human cells using Drosophila gene products. RNA 23, 153-160. https://doi.org/10.1261/rna.059345.116

Khong, A., Kerr, C.H., Yeung, C.H.L., Keatings, K., Nayak, A., Allan, D.W., Jan, E., 2017. Disruption of Stress Granule Formation by the Multifunctional Cricket Paralysis Virus 1A Protein. J. Virol. 91. https://doi.org/10.1128/JVI.01779-16

Kolakofsky, D., Kowalinski, E., Cusack, S., 2012. A structure-based model of RIG-I activation. RNA 18, 2118-2127. https://doi.org/10.1261/rna.035949.112

Kosakamoto, H., Yamauchi, T., Akuzawa-Tokita, Y., Nishimura, K., Soga, T., Murakami, T., Mori, H., Yamamoto, K., Miyazaki, R., Koto, A., Miura, M., Obata, F., 2020. Local Necrotic Cells Trigger Systemic Immune Activation via Gut Microbiome Dysbiosis in Drosophila. Cell Rep 32, 107938. https://doi.org/10.1016/j.celrep.2020.107938

Kowalinski, E., Lunardi, T., McCarthy, A.A., Louber, J., Brunel, J., Grigorov, B., Gerlier, D., Cusack, S., 2011. Structural basis for the activation of innate immune pattern-recognition receptor RIG-I by viral RNA. Cell 147, 423-435. https://doi.org/10.1016/j.cell.2011.09.039

Kranzusch, P.J., Wilson, S.C., Lee, A.S.Y., Berger, J.M., Doudna, J.A., Vance, R.E., 2015. Ancient Origin of cGAS-STING Reveals Mechanism of Universal 2',3' cGAMP Signaling. Mol. Cell 59, 891-903. https://doi.org/10.1016/j.molcel.2015.07.022

Lacey, L.A., Grzywacz, D., Shapiro-Ilan, D.I., Frutos, R., Brownbridge, M., Goettel, M.S., 2015. Insect pathogens as biological control agents: Back to the future. J. Invertebr. Pathol. 132, 1-41. https://doi.org/10.1016/j.jip.2015.07.009

Lafont, M., Petton, B., Vergnes, A., Pauletto, M., Segarra, A., Gourbal, B., Montagnani, C., 2017. Long-lasting antiviral innate immune priming in the Lophotrochozoan Pacific oyster, Crassostrea gigas. Sci Rep 7, 13143. https://doi.org/10.1038/s41598-017-13564-0

Lafont, M., Vergnes, A., Vidal-Dupiol, J., de Lorgeril, J., Gueguen, Y., Haffner, P., Petton, B., Chaparro, C., Barrachina, C., Destoumieux-Garzon, D., Mitta, G., Gourbal, B., Montagnani, C., 2020. A Sustained Immune Response Supports Long-Term Antiviral Immune Priming in the Pacific Oyster, Crassostrea gigas. mBio 11. https://doi.org/10.1128/mBio.02777-19

Lamiable, O., Arnold, J., de Faria, I.J. da S., Olmo, R.P., Bergami, F., Meignin, C., Hoffmann, J.A., Marques, J.T., Imler, J.-L., 2016a. Analysis of the Contribution of Hemocytes and Autophagy to Drosophila Antiviral Immunity. J. Virol. 90, 5415-5426. https://doi.org/10.1128/JVI.00238-16

Lamiable, O., Kellenberger, C., Kemp, C., Troxler, L., Pelte, N., Boutros, M., Marques, J.T., Daeffler, L., Hoffmann, J.A., Roussel, A., Imler, J.-L., 2016b. Cytokine Diedel and a viral homologue suppress the IMD pathway in Drosophila. Proc. Natl. Acad. Sci. U.S.A. 113, 698-703. https://doi.org/10.1073/pnas.1516122113

Lee, Y.S., Nakahara, K., Pham, J.W., Kim, K., He, Z., Sontheimer, E.J., Carthew, R.W., 2004. Distinct roles for Drosophila Dicer-1 and Dicer-2 in the siRNA/miRNA silencing pathways. Cell 117, 69-81.

Lemaitre, B., Hoffmann, J., 2007. The host defense of Drosophila melanogaster. Annu. Rev. Immunol. 25, 697-743. https://doi.org/10.1146/annurev.immunol.25.022106.141615

Lemaitre, B., Meister, M., Govind, S., Georgel, P., Steward, R., Reichhart, J.M., Hoffmann, J.A., 1995. Functional analysis and regulation of nuclear import of dorsal during the immune response in Drosophila. EMBO J. 14, 536-545.

Letourneau, M., Lapraz, F., Sharma, A., Vanzo, N., Waltzer, L., Crozatier, M., 2016. Drosophila hematopoiesis under normal conditions and in response to immune stress. FEBS Lett. 590, 4034-4051. https://doi.org/10.1002/1873-3468.12327

Lewis, S.H., Quarles, K.A., Yang, Y., Tanguy, M., Frézal, L., Smith, S.A., Sharma, P.P., Cordaux, R., Gilbert, C., Giraud, I., Collins, D.H., Zamore, P.D., Miska, E.A., Sarkies, 
P., Jiggins, F.M., 2018. Pan-arthropod analysis reveals somatic piRNAs as an ancestral defence against transposable elements. Nat Ecol Evol 2, 174-181.

https://doi.org/10.1038/s41559-017-0403-4

Lhéritier, P., 1958. The Hereditary Virus of Drosophila. Advances in Virus Research 5, 195245. https://doi.org/10.1016/S0065-3527(08)60674-0

Lim, D.-H., Oh, C.-T., Lee, L., Hong, J.-S., Noh, S.-H., Hwang, S., Kim, S., Han, S.-J., Lee, Y.S., 2011. The endogenous siRNA pathway in Drosophila impacts stress resistance and lifespan by regulating metabolic homeostasis. FEBS Letters 585, 3079-3085. https://doi.org/10.1016/j.febslet.2011.08.034

Liu, B., Behura, S.K., Clem, R.J., Schneemann, A., Becnel, J., Severson, D.W., Zhou, L., 2013. P53-mediated rapid induction of apoptosis conveys resistance to viral infection in Drosophila melanogaster. PLoS Pathog 9, e1003137. https://doi.org/10.1371/journal.ppat.1003137

Liu, X., Hodgson, J.J., Buchon, N., 2017. Drosophila as a model for homeostatic, antibacterial, and antiviral mechanisms in the gut. PLoS Pathog. 13, e1006277. https://doi.org/10.1371/journal.ppat.1006277

Liu, Y., Gordesky-Gold, B., Leney-Greene, M., Weinbren, N.L., Tudor, M., Cherry, S., 2018. Inflammation-Induced, STING-Dependent Autophagy Restricts Zika Virus Infection in the Drosophila Brain. Cell Host Microbe 24, 57-68.e3. https://doi.org/10.1016/j.chom.2018.05.022

Lü, P., Pan, Y., Yang, Y., Zhu, F., Li, C., Guo, Z., Yao, Q., Chen, K., 2018. Discovery of anti-viral molecules and their vital functions in Bombyx mori. J Invertebr Pathol 154, 12 18. https://doi.org/10.1016/j.jip.2018.02.012

Majzoub, K., Hafirassou, M.L., Meignin, C., Goto, A., Marzi, S., Fedorova, A., Verdier, Y., Vinh, J., Hoffmann, J.A., Martin, F., Baumert, T.F., Schuster, C., Imler, J.-L., 2014. RACK1 controls IRES-mediated translation of viruses. Cell 159, 1086-1095. https://doi.org/10.1016/j.cell.2014.10.041

Manley, R., Boots, M., Wilfert, L., 2015. Emerging viral disease risk to pollinating insects: ecological, evolutionary and anthropogenic factors. J Appl Ecol 52, 331-340. https://doi.org/10.1111/1365-2664.12385

Margolis, S.R., Wilson, S.C., Vance, R.E., 2017. Evolutionary Origins of cGAS-STING Signaling. Trends Immunol. 38, 733-743. https://doi.org/10.1016/j.it.2017.03.004

Marques, J.T., Kim, K., Wu, P.-H., Alleyne, T.M., Jafari, N., Carthew, R.W., 2010. Loqs and R2D2 act sequentially in the siRNA pathway in Drosophila. Nat. Struct. Mol. Biol. 17, 24-30. https://doi.org/10.1038/nsmb.1735

Marques, J.T., Wang, J.-P., Wang, X., de Oliveira, K.P.V., Gao, C., Aguiar, E.R.G.R., Jafari, N., Carthew, R.W., 2013. Functional specialization of the small interfering RNA pathway in response to virus infection. PLoS Pathog. 9, e1003579. https://doi.org/10.1371/journal.ppat.1003579

Martin, M., Hiroyasu, A., Guzman, R.M., Roberts, S.A., Goodman, A.G., 2018. Analysis of Drosophila STING Reveals an Evolutionarily Conserved Antimicrobial Function. Cell Rep 23, 3537-3550.e6. https://doi.org/10.1016/j.celrep.2018.05.029

Martins, N., Lemoine, A., Santiago, E., Paro, S., Imler, J.-L., Meignin, C., 2019. A Transgenic Flock House Virus Replicon Reveals an RNAi Independent Antiviral Mechanism Acting in Drosophila Follicular Somatic Cells. G3 (Bethesda) 9, 403-412. https://doi.org/10.1534/g3.118.200872

Martins, N.E., 2020. Towards a Mechanism for Poly(I. C) Antiviral Priming in Oysters. mBio 11. https://doi.org/10.1128/mBio.00407-20

Martins, N.E., Faria, V.G., Teixeira, L., Magalhães, S., Sucena, É., 2013. Host adaptation is contingent upon the infection route taken by pathogens. PLoS Pathog. 9, e1003601. 
https://doi.org/10.1371/journal.ppat.1003601

Merkling, S.H., Bronkhorst, A.W., Kramer, J.M., Overheul, G.J., Schenck, A., Van Rij, R.P., 2015a. The epigenetic regulator G9a mediates tolerance to RNA virus infection in Drosophila. PLoS Pathog. 11, e1004692. https://doi.org/10.1371/journal.ppat.1004692

Merkling, S.H., Overheul, G.J., van Mierlo, J.T., Arends, D., Gilissen, C., van Rij, R.P., 2015b. The heat shock response restricts virus infection in Drosophila. Sci Rep 5, 12758. https://doi.org/10.1038/srep12758

Miesen, P., Joosten, J., van Rij, R.P., 2016. PIWIs Go Viral: Arbovirus-Derived piRNAs in Vector Mosquitoes. PLoS Pathog. 12, e1006017. https://doi.org/10.1371/journal.ppat.1006017

Ming, M., Obata, F., Kuranaga, E., Miura, M., 2014. Persephone/Spätzle pathogen sensors mediate the activation of Toll receptor signaling in response to endogenous danger signals in apoptosis-deficient Drosophila. J. Biol. Chem. 289, 7558-7568. https://doi.org/10.1074/jbc.M113.543884

Misof, B., Liu, S., Meusemann, K., Peters, R.S., Donath, A., Mayer, C., Frandsen, P.B., Ware, J., Flouri, T., Beutel, R.G., Niehuis, O., Petersen, M., Izquierdo-Carrasco, F., Wappler, T., Rust, J., Aberer, A.J., Aspöck, U., Aspöck, H., Bartel, D., Blanke, A., Berger, S., Böhm, A., Buckley, T.R., Calcott, B., Chen, J., Friedrich, F., Fukui, M., Fujita, M., Greve, C., Grobe, P., Gu, S., Huang, Y., Jermiin, L.S., Kawahara, A.Y., Krogmann, L., Kubiak, M., Lanfear, R., Letsch, H., Li, Yiyuan, Li, Z., Li, J., Lu, H., Machida, R., Mashimo, Y., Kapli, P., McKenna, D.D., Meng, G., Nakagaki, Y., Navarrete-Heredia, J.L., Ott, M., Ou, Y., Pass, G., Podsiadlowski, L., Pohl, H., von Reumont, B.M., Schütte, K., Sekiya, K., Shimizu, S., Slipinski, A., Stamatakis, A., Song, W., Su, X., Szucsich, N.U., Tan, M., Tan, X., Tang, M., Tang, J., Timelthaler, G., Tomizuka, S., Trautwein, M., Tong, X., Uchifune, T., Walzl, M.G., Wiegmann, B.M., Wilbrandt, J., Wipfler, B., Wong, T.K.F., Wu, Q., Wu, G., Xie, Y., Yang, S., Yang, Q., Yeates, D.K., Yoshizawa, K., Zhang, Q., Zhang, R., Zhang, W., Zhang, Yunhui, Zhao, J., Zhou, C., Zhou, L., Ziesmann, T., Zou, S., Li, Yingrui, Xu, X., Zhang, Yong, Yang, H., Wang, Jian, Wang, Jun, Kjer, K.M., Zhou, X., 2014. Phylogenomics resolves the timing and pattern of insect evolution. Science 346, 763-767. https://doi.org/10.1126/science. 1257570

Mlih, M., Khericha, M., Birdwell, C., West, A.P., Karpac, J., 2018. A virus-acquired host cytokine controls systemic aging by antagonizing apoptosis. PLoS Biol. 16, e2005796. https://doi.org/10.1371/journal.pbio.2005796

Mondotte, J.A., Gausson, V., Frangeul, L., Blanc, H., Lambrechts, L., Saleh, M.-C., 2018. Immune priming and clearance of orally acquired RNA viruses in Drosophila. Nat Microbiol 3, 1394-1403. https://doi.org/10.1038/s41564-018-0265-9

Mondotte, J.A., Saleh, M.-C., 2018. Antiviral Immune Response and the Route of Infection in Drosophila melanogaster. Adv. Virus Res. 100, 247-278. https://doi.org/10.1016/bs.aivir.2017.10.006

Monsanto-Hearne, V., Asad, S., Asgari, S., Johnson, K.N., 2017a. Drosophila microRNA modulates viral replication by targeting a homologue of mammalian cJun. J. Gen. Virol. 98, 1904-1912. https://doi.org/10.1099/jgv.0.000831

Monsanto-Hearne, V., Tham, A.L.Y., Wong, Z.S., Asgari, S., Johnson, K.N., $2017 \mathrm{~b}$. Drosophila miR-956 suppression modulates Ectoderm-expressed 4 and inhibits viral replication. Virology 502, 20-27. https://doi.org/10.1016/j.virol.2016.12.009

Morehouse, B.R., Govande, A.A., Millman, A., Keszei, A.F.A., Lowey, B., Ofir, G., Shao, S., Sorek, R., Kranzusch, P.J., 2020. STING cyclic dinucleotide sensing originated in bacteria. Nature 586, 429-433. https://doi.org/10.1038/s41586-020-2719-5

Mueller, S., Gausson, V., Vodovar, N., Deddouche, S., Troxler, L., Perot, J., Pfeffer, S., 
Hoffmann, J.A., Saleh, M.-C., Imler, J.-L., 2010. RNAi-mediated immunity provides strong protection against the negative-strand RNA vesicular stomatitis virus in Drosophila. Proc. Natl. Acad. Sci. U.S.A. 107, 19390-19395. https://doi.org/10.1073/pnas.1014378107

Mussabekova, A., Daeffler, L., Imler, J.-L., 2017. Innate and intrinsic antiviral immunity in Drosophila. Cell. Mol. Life Sci. 74, 2039-2054. https://doi.org/10.1007/s00018-0172453-9

Nainu, F., Tanaka, Y., Shiratsuchi, A., Nakanishi, Y., 2015. Protection of Insects against Viral Infection by Apoptosis-Dependent Phagocytosis. J. Immunol. 195, 5696-5706. https://doi.org/10.4049/jimmunol.1500613

Nandy, A., Lin, L., Velentzas, P.D., Wu, L.P., Baehrecke, E.H., Silverman, N., 2018. The NF- $\kappa$ B Factor Relish Regulates Atg1 Expression and Controls Autophagy. Cell Rep 25, 2110-2120.e3. https://doi.org/10.1016/j.celrep.2018.10.076

Nayak, A., Kim, D.Y., Trnka, M.J., Kerr, C.H., Lidsky, P.V., Stanley, D.J., Rivera, B.M., Li, K.H., Burlingame, A.L., Jan, E., Frydman, J., Gross, J.D., Andino, R., 2018. A Viral Protein Restricts Drosophila RNAi Immunity by Regulating Argonaute Activity and Stability. Cell Host \& Microbe 24, 542-557.e9. https://doi.org/10.1016/j.chom.2018.09.006

Nayak, A., Tassetto, M., Kunitomi, M., Andino, R., 2013. RNA interference-mediated intrinsic antiviral immunity in invertebrates. Curr. Top. Microbiol. Immunol. 371, 183200. https://doi.org/10.1007/978-3-642-37765-5_7

Nitschko, V., Kunzelmann, S., Fröhlich, T., Arnold, G.J., Förstemann, K., 2020. Trafficking of siRNA precursors by the dsRBD protein Blanks in Drosophila. Nucleic Acids Res. 48, 3906-3921. https://doi.org/10.1093/nar/gkaa072

Olmo, R.P., Ferreira, A.G.A., Izidoro-Toledo, T.C., Aguiar, E.R.G.R., de Faria, I.J.S., de Souza, K.P.R., Osório, K.P., Kuhn, L., Hammann, P., de Andrade, E.G., Todjro, Y.M., Rocha, M.N., Leite, T.H.J.F., Amadou, S.C.G., Armache, J.N., Paro, S., de Oliveira, C.D., Carvalho, F.D., Moreira, L.A., Marois, E., Imler, J.-L., Marques, J.T., 2018. Control of dengue virus in the midgut of Aedes aegypti by ectopic expression of the dsRNA-binding protein Loqs2. Nat Microbiol 3, 1385-1393. https://doi.org/10.1038/s41564-018-0268-6

Palmer, W.H., Dittmar, M., Gordesky-Gold, B., Hofmann, J., Cherry, S., 2020. Drosophila melanogaster as a model for arbovirus infection of adult salivary glands. Virology 543, 1-6. https://doi.org/10.1016/j.virol.2020.01.010

Palmer, W.H., Joosten, J., Overheul, G.J., Jansen, P.W., Vermeulen, M., Obbard, D.J., Van Rij, R.P., 2019. Induction and Suppression of NF- $\kappa$ B Signalling by a DNA Virus of Drosophila. J. Virol. 93. https://doi.org/10.1128/JVI.01443-18

Palmer, W.H., Medd, N.C., Beard, P.M., Obbard, D.J., 2018a. Isolation of a natural DNA virus of Drosophila melanogaster, and characterisation of host resistance and immune responses. PLoS Pathog. 14, e1007050. https://doi.org/10.1371/journal.ppat.1007050

Palmer, W.H., Varghese, F.S., van Rij, R.P., 2018b. Natural Variation in Resistance to Virus Infection in Dipteran Insects. Viruses 10. https://doi.org/10.3390/v10030118

Panda, D., Rose, P.P., Hanna, S.L., Gold, B., Hopkins, K.C., Lyde, R.B., Marks, M.S., Cherry, S., 2013. Genome-wide RNAi screen identifies SEC61A and VCP as conserved regulators of Sindbis virus entry. Cell Rep 5, 1737-1748. https://doi.org/10.1016/j.celrep.2013.11.028

Paradkar, P.N., Trinidad, L., Voysey, R., Jean-Bernard Duchemin, Walker, P.J., 2012. Secreted Vago restricts West Nile virus infection in Culex mosquito cells by activating the Jak-STAT pathway. Proc. Natl. Acad. Sci. U.S.A. 109, 18915-18920. https://doi.org/10.1073/pnas.1205231109 
Pélisson, A., Sarot, E., Payen-Groschêne, G., Bucheton, A., 2007. A novel repeat-associated small interfering RNA-mediated silencing pathway downregulates complementary sense gypsy transcripts in somatic cells of the Drosophila ovary. J. Virol. 81, 1951-1960. https://doi.org/10.1128/JVI.01980-06

Perrimon, N., Mahowald, A.P., 1986. 1(1)hopscotch, A larval-pupal zygotic lethal with a specific maternal effect on segmentation in Drosophila. Dev Biol 118, $28-41$. https://doi.org/10.1016/0012-1606(86)90070-9

Petit, M., Mongelli, V., Frangeul, L., Blanc, H., Jiggins, F., Saleh, M.-C., 2016. piRNA pathway is not required for antiviral defense in Drosophila melanogaster. Proc. Natl. Acad. Sci. U.S.A. 113, E4218-4227. https://doi.org/10.1073/pnas.1607952113

Poirier, E.Z., Goic, B., Tomé-Poderti, L., Frangeul, L., Boussier, J., Gausson, V., Blanc, H., Vallet, T., Loyd, H., Levi, L.I., Lanciano, S., Baron, C., Merkling, S.H., Lambrechts, L., Mirouze, M., Carpenter, S., Vignuzzi, M., Saleh, M.-C., 2018. Dicer-2-Dependent Generation of Viral DNA from Defective Genomes of RNA Viruses Modulates Antiviral Immunity in Insects. Cell Host Microbe 23, 353-365.e8. https://doi.org/10.1016/j.chom.2018.02.001

Roers, A., Hiller, B., Hornung, V., 2016. Recognition of Endogenous Nucleic Acids by the Innate Immune System. Immunity 44, 739-754. https://doi.org/10.1016/j.immuni.2016.04.002

Roignant, J.-Y., Carré, C., Mugat, B., Szymczak, D., Lepesant, J.-A., Antoniewski, C., 2003. Absence of transitive and systemic pathways allows cell-specific and isoform-specific RNAi in Drosophila. RNA 9, 299-308.

Rutschmann, S., Jung, A.C., Hetru, C., Reichhart, J.M., Hoffmann, J.A., Ferrandon, D., 2000. The Rel protein DIF mediates the antifungal but not the antibacterial host defense in Drosophila. Immunity 12, 569-580.

Sabin, L.R., Zheng, Q., Thekkat, P., Yang, J., Hannon, G.J., Gregory, B.D., Tudor, M., Cherry, S., 2013. Dicer-2 processes diverse viral RNA species. PLoS ONE 8, e55458. https://doi.org/10.1371/journal.pone.0055458

Saito, K., Nishida, K.M., Mori, T., Kawamura, Y., Miyoshi, K., Nagami, T., Siomi, H., Siomi, M.C., 2006. Specific association of Piwi with rasiRNAs derived from retrotransposon and heterochromatic regions in the Drosophila genome. Genes Dev. 20, 2214-2222. https://doi.org/10.1101/gad.1454806

Saleh, M.-C., Tassetto, M., van Rij, R.P., Goic, B., Gausson, V., Berry, B., Jacquier, C., Antoniewski, C., Andino, R., 2009. Antiviral immunity in Drosophila requires systemic RNA interference spread. Nature 458, 346-350. https://doi.org/10.1038/nature07712

Sansone, C.L., Cohen, J., Yasunaga, A., Xu, J., Osborn, G., Subramanian, H., Gold, B., Buchon, N., Cherry, S., 2015. Microbiota-Dependent Priming of Antiviral Intestinal Immunity in Drosophila. Cell Host Microbe 18, 571-581. https://doi.org/10.1016/j.chom.2015.10.010

Schuster, S., Miesen, P., van Rij, R.P., 2019. Antiviral RNAi in Insects and Mammals: Parallels and Differences. Viruses 11. https://doi.org/10.3390/v11050448

Segrist, E., Cherry, S., 2020. Using Diverse Model Systems to Define Intestinal Epithelial Defenses to Enteric Viral Infections. Cell Host Microbe 27, 329-344. https://doi.org/10.1016/j.chom.2020.02.003

Sen, G.C., Peters, G.A., 2007. Viral stress-inducible genes. Adv Virus Res 70, 233-263. https://doi.org/10.1016/S0065-3527(07)70006-4

Senti, K.-A., Brennecke, J., 2010. The piRNA pathway: a fly's perspective on the guardian of the genome. Trends in Genetics 26, 499-509. https://doi.org/10.1016/j.tig.2010.08.007

Shaw, W.R., Catteruccia, F., 2019. Vector biology meets disease control: using basic research to fight vector-borne diseases. Nat Microbiol 4, 20-34. https://doi.org/10.1038/s41564- 
018-0214-7

Shi, M., Lin, X.-D., Tian, J.-H., Chen, L.-J., Chen, X., Li, C.-X., Qin, X.-C., Li, J., Cao, J.-P., Eden, J.-S., Buchmann, J., Wang, W., Xu, J., Holmes, E.C., Zhang, Y.-Z., 2016. Redefining the invertebrate RNA virosphere. Nature 540, 539-543. https://doi.org/10.1038/nature20167

Sinha, N.K., Iwasa, J., Shen, P.S., Bass, B.L., 2018. Dicer uses distinct modules for recognizing dsRNA termini. Science 359, 329-334. https://doi.org/10.1126/science.aaq0921

Sinha, N.K., Trettin, K.D., Aruscavage, P.J., Bass, B.L., 2015. Drosophila Dicer-2 Cleavage Is Mediated by Helicase- and dsRNA Termini-Dependent States that Are Modulated by Loquacious-PD. Molecular Cell 58, 406-417. https://doi.org/10.1016/j.molcel.2015.03.012

Siomi, M.C., Sato, K., Pezic, D., Aravin, A.A., 2011. PIWI-interacting small RNAs: the vanguard of genome defence. Nat Rev Mol Cell Biol 12, 246-258. https://doi.org/10.1038/nrm3089

Srinivasan, N., Gordon, O., Ahrens, S., Franz, A., Deddouche, S., Chakravarty, P., Phillips, D., Yunus, A.A., Rosen, M.K., Valente, R.S., Teixeira, L., Thompson, B., Dionne, M.S., Wood, W., Reis e Sousa, C., 2016. Actin is an evolutionarily-conserved damageassociated molecular pattern that signals tissue injury in Drosophila melanogaster. Elife 5. https://doi.org/10.7554/eLife.19662

Swevers, L., Liu, J., Smagghe, G., 2018. Defense Mechanisms against Viral Infection in Drosophila: RNAi and Non-RNAi. Viruses 10. https://doi.org/10.3390/v10050230

Talide, L., Imler, J.-L., Meignin, C., 2020. Sensing Viral Infections in Insects: A Dearth of Pathway Receptors. Curr Issues Mol Biol 34, 31-60. https://doi.org/10.21775/cimb.034.031

Tang, H., Kambris, Z., Lemaitre, B., Hashimoto, C., 2008. A serpin that regulates immune melanization in the respiratory system of Drosophila. Dev. Cell 15, 617-626. https://doi.org/10.1016/j.devcel.2008.08.017

Tassetto, M., Kunitomi, M., Andino, R., 2017. Circulating Immune Cells Mediate a Systemic RNAi-Based Adaptive Antiviral Response in Drosophila. Cell 169, 314-325.e13. https://doi.org/10.1016/j.cell.2017.03.033

Tavignot, R., Chaduli, D., Djitte, F., Charroux, B., Royet, J., 2017. Inhibition of a NF$\kappa B / D i a p 1$ Pathway by PGRP-LF Is Required for Proper Apoptosis during Drosophila Development. PLoS Genet. 13, e1006569. https://doi.org/10.1371/journal.pgen.1006569

Teixeira, L., Ferreira, A., Ashburner, M., 2008. The bacterial symbiont Wolbachia induces resistance to RNA viral infections in Drosophila melanogaster. PLoS Biol. 6, e2. https://doi.org/10.1371/journal.pbio.1000002

tenOever, B.R., 2016. The Evolution of Antiviral Defense Systems. Cell Host Microbe 19, 142-149. https://doi.org/10.1016/j.chom.2016.01.006

Trettin, K.D., Sinha, N.K., Eckert, D.M., Apple, S.E., Bass, B.L., 2017. Loquacious-PD facilitates Drosophila Dicer-2 cleavage through interactions with the helicase domain and dsRNA. Proc. Natl. Acad. Sci. U.S.A. 114, E7939-E7948.

https://doi.org/10.1073/pnas.1707063114

Tuddenham, L., Pfeffer, S., 2011. Roles and regulation of microRNAs in cytomegalovirus infection. Biochim. Biophys. Acta 1809, 613-622.

https://doi.org/10.1016/j.bbagrm.2011.04.002

Vagin, V.V., Sigova, A., Li, C., Seitz, H., Gvozdev, V., Zamore, P.D., 2006. A distinct small RNA pathway silences selfish genetic elements in the germline. Science 313, 320-324. https://doi.org/10.1126/science.1129333

van Rij, R.P., Saleh, M.-C., Berry, B., Foo, C., Houk, A., Antoniewski, C., Andino, R., 2006. 
The RNA silencing endonuclease Argonaute 2 mediates specific antiviral immunity in Drosophila melanogaster. Genes Dev. 20, 2985-2995. https://doi.org/10.1101/gad.1482006

Vodovar, N., Goic, B., Blanc, H., Saleh, M.-C., 2011. In silico reconstruction of viral genomes from small RNAs improves virus-derived small interfering RNA profiling. J Virol 85, 11016-11021. https://doi.org/10.1128/JVI.05647-11

Waldron, F.M., Stone, G.N., Obbard, D.J., 2018. Metagenomic sequencing suggests a diversity of RNA interference-like responses to viruses across multicellular eukaryotes. PLoS Genet. 14, e1007533. https://doi.org/10.1371/journal.pgen.1007533

Wang, H., Smagghe, G., Meeus, I., 2017. The role of a single gene encoding the Single von Willebrand factor C-domain protein (SVC) in bumblebee immunity extends beyond antiviral defense. Insect Biochem. Mol. Biol. 91, 10-20. https://doi.org/10.1016/j.ibmb.2017.10.002

Wang, L., Sexton, T.R., Venard, C., Giedt, M., Guo, Q., Chen, Q., Harrison, D.A., 2014. Pleiotropy of the Drosophila JAK pathway cytokine Unpaired 3 in development and aging. Dev Biol 395, 218-231. https://doi.org/10.1016/j.ydbio.2014.09.015

Wang, X.-H., Aliyari, R., Li, W.-X., Li, H.-W., Kim, K., Carthew, R., Atkinson, P., Ding, S.W., 2006. RNA interference directs innate immunity against viruses in adult Drosophila. Science 312, 452-454. https://doi.org/10.1126/science.1125694

Wang, Z., Xia, X., Yang, X., Zhang, X., Liu, Yongxiang, Wu, D., Fang, Y., Liu, Yujie, Xu, J., Qiu, Y., Zhou, X., 2017. A picorna-like virus suppresses the N-end rule pathway to inhibit apoptosis. Elife 6. https://doi.org/10.7554/eLife.30590

Wangler, M.F., Yamamoto, S., Bellen, H.J., 2015. Fruit flies in biomedical research. Genetics 199, 639-653. https://doi.org/10.1534/genetics.114.171785

Watanabe, M., Iwakawa, H.-O., Tadakuma, H., Tomari, Y., 2017. Biochemical and singlemolecule analyses of the RNA silencing suppressing activity of CrPV-1A. Nucleic Acids Res 45, 10837-10844. https://doi.org/10.1093/nar/gkx748

Weavers, H., Evans, I.R., Martin, P., Wood, W., 2016. Corpse Engulfment Generates a Molecular Memory that Primes the Macrophage Inflammatory Response. Cell 165, 1658-1671. https://doi.org/10.1016/j.cell.2016.04.049

Webster, C.L., Waldron, F.M., Robertson, S., Crowson, D., Ferrari, G., Quintana, J.F., Brouqui, J.-M., Bayne, E.H., Longdon, B., Buck, A.H., Lazzaro, B.P., Akorli, J., Haddrill, P.R., Obbard, D.J., 2015. The Discovery, Distribution, and Evolution of Viruses Associated with Drosophila melanogaster. PLoS Biol. 13, e1002210. https://doi.org/10.1371/journal.pbio.1002210

West, C., Rus, F., Chen, Y., Kleino, A., Gangloff, M., Gammon, D.B., Silverman, N., 2019. IIV-6 Inhibits NF-kB Responses in Drosophila. Viruses 11, 409. https://doi.org/10.3390/v11050409

West, C., Silverman, N., 2018. p38b and JAK-STAT signaling protect against Invertebrate iridescent virus 6 infection in Drosophila. PLoS Pathog. 14, e1007020. https://doi.org/10.1371/journal.ppat.1007020

Wright, V.M., Vogt, K.L., Smythe, E., Zeidler, M.P., 2011. Differential activities of the Drosophila JAK/STAT pathway ligands Upd, Upd2 and Upd3. Cell Signal 23, 920-927. https://doi.org/10.1016/j.cellsig.2011.01.020

Wu, Q., Luo, Y., Lu, R., Lau, N., Lai, E.C., Li, W.-X., Ding, S.-W., 2010. Virus discovery by deep sequencing and assembly of virus-derived small silencing RNAs. Proc. Natl. Acad. Sci. U.S.A. 107, 1606-1611. https://doi.org/10.1073/pnas.0911353107

Wu, X., Wu, F.-H., Wang, X., Wang, L., Siedow, J.N., Zhang, W., Pei, Z.-M., 2014. Molecular evolutionary and structural analysis of the cytosolic DNA sensor cGAS and STING. Nucleic Acids Res. 42, 8243-8257. https://doi.org/10.1093/nar/gku569 
Xu, J., Grant, G., Sabin, L.R., Gordesky-Gold, B., Yasunaga, A., Tudor, M., Cherry, S., 2012. Transcriptional pausing controls a rapid antiviral innate immune response in Drosophila. Cell Host Microbe 12, 531-543. https://doi.org/10.1016/j.chom.2012.08.011

Xu, J., Hopkins, K., Sabin, L., Yasunaga, A., Subramanian, H., Lamborn, I., Gordesky-Gold, B., Cherry, S., 2013. ERK signaling couples nutrient status to antiviral defense in the insect gut. Proc Natl Acad Sci U S A 110, 15025-15030. https://doi.org/10.1073/pnas.1303193110

Yan, R., Small, S., Desplan, C., Dearolf, C.R., Darnell, J.E., 1996. Identification of a Stat gene that functions in Drosophila development. Cell 84, 421-430. https://doi.org/10.1016/s0092-8674(00)81287-8

Zambon, R.A., Nandakumar, M., Vakharia, V.N., Wu, L.P., 2005. The Toll pathway is important for an antiviral response in Drosophila. Proceedings of the National Academy of Sciences 102, 7257-7262. https://doi.org/10.1073/pnas.0409181102

Zeidler, M.P., Bausek, N., 2013. The Drosophila JAK-STAT pathway. JAKSTAT 2, e25353. https://doi.org/10.4161/jkst.25353

Zhai, Z., Boquete, J.-P., Lemaitre, B., 2018. Cell-Specific Imd-NF-кB Responses Enable Simultaneous Antibacterial Immunity and Intestinal Epithelial Cell Shedding upon Bacterial Infection. Immunity 48, 897-910.e7. https://doi.org/10.1016/j.immuni.2018.04.010

Zhang, L., Xu, W., Gao, X., Li, W., Qi, S., Guo, D., Ajayi, O.E., Ding, S.-W., Wu, Q., 2020. lncRNA Sensing of a Viral Suppressor of RNAi Activates Non-canonical Innate Immune Signaling in Drosophila. Cell Host Microbe 27, 115-128.e8. https://doi.org/10.1016/j.chom.2019.12.006

Zhang, Q., Zhang, L., Gao, X., Qi, S., Chang, Z., Wu, Q., 2015. DIP1 plays an antiviral role against DCV infection in Drosophila melanogaster. Biochem. Biophys. Res. Commun. 460, 222-226. https://doi.org/10.1016/j.bbrc.2015.03.013

Figure 1. Inducible antiviral responses in drosophila. The main signalling pathways associated with antiviral immunity in $D$. melanogaster are shown. Some responses are thought to be induced in infected cells, upon sensing infection (e.g. STING pathway), while others occur in response to cytokines (e.g. Diedel, Spätzle, Upd). Infected dying cells can release cellular components (e.g. $\alpha$-actinin), detected as danger signals in a paracrine manner by other cells. Viral suppressors targeting these pathways are shown as orange triangles. See the text for details. 


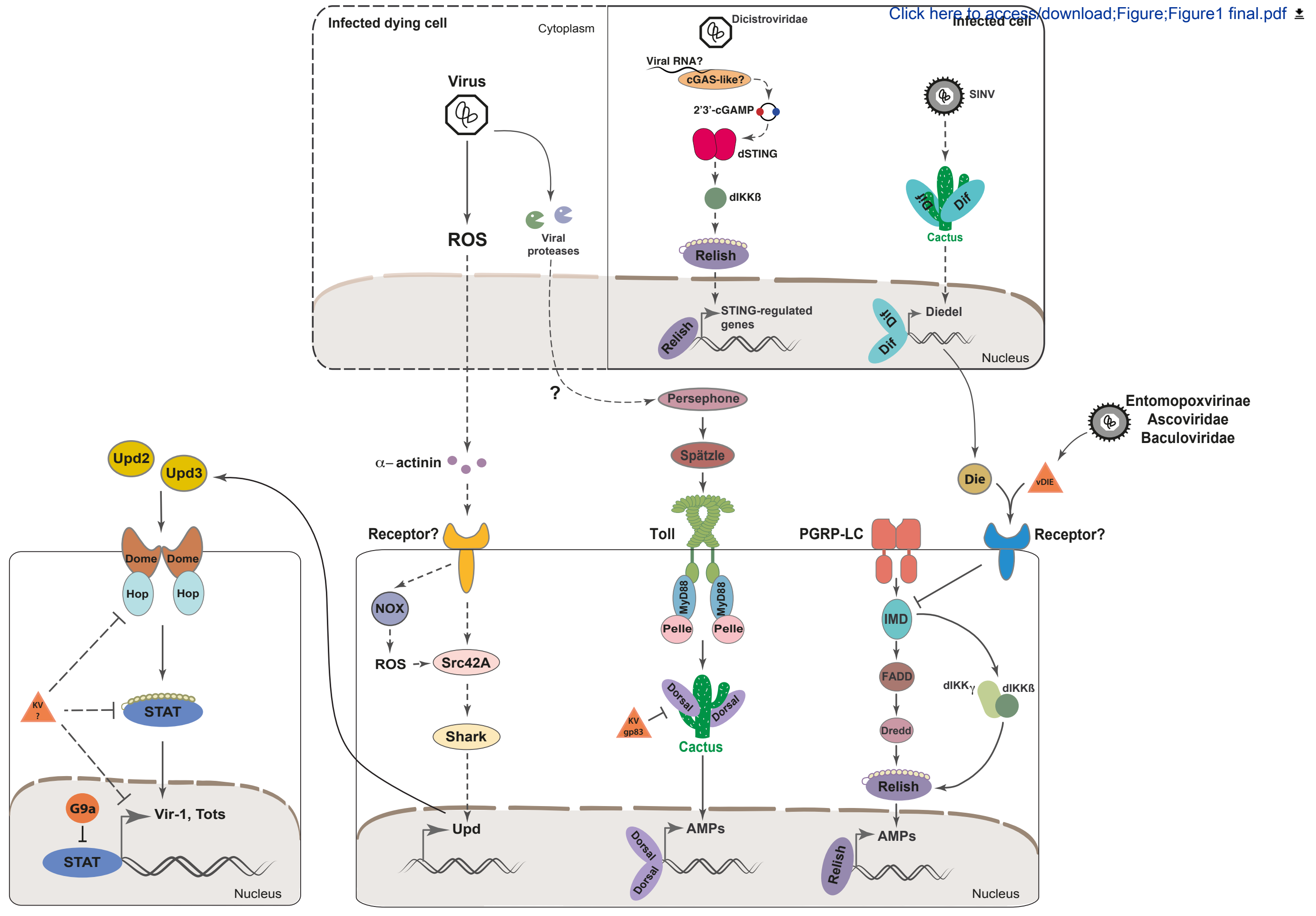

Figure1 Review JS and JLI 


\begin{tabular}{|c|c|c|c|c|c|}
\hline \multirow{2}{*}{ Name } & \multirow{2}{*}{ Family } & \multirow{2}{*}{ Genome } & \multicolumn{3}{|c|}{ Identified immune suppressor } \\
\hline & & & Name & Targeted pathway & Mechanism \\
\hline $\begin{array}{l}\text { Drosophila } C \\
\text { virus (DCV) }\end{array}$ & Dicistroviridae & $\operatorname{ssRNA}(+)$ & DCV-1A & SiRNA & $\begin{array}{c}\text { dsRNA binding protein: long } \\
\text { dsRNA }\end{array}$ \\
\hline $\begin{array}{l}\text { Cricket Paralysis } \\
\text { virus (CrPV) }\end{array}$ & Dicistroviridae & $\operatorname{ssRNA}(+)$ & CrPV-1A & siRNA; transcription & $\begin{array}{c}\text { AGO2 binding: inhibition \& } \\
\text { degradation }\end{array}$ \\
\hline $\begin{array}{l}\text { Sindbis birus } \\
\text { (SINV) }\end{array}$ & Togaviridae & $\operatorname{ssRNA}(+)$ & / & / & / \\
\hline $\begin{array}{l}\text { Flock House } \\
\text { virus (FHV) }\end{array}$ & Nodaviridae & $\operatorname{ssRNA}(+)$ & FHV-B2 & SiRNA & $\begin{array}{l}\text { dsRNA binding protein: long } \\
\text { dsRNA \& siRNA duplexes }\end{array}$ \\
\hline Nora virus & Unclassified & $\operatorname{ssRNA}(+)$ & Nora-VP1 & SiRNA & AGO2 binding: inhibition \\
\hline Sigma virus (SV) & Rhabdoviridae & $\operatorname{ssRNA}(-)$ & / & / & / \\
\hline $\begin{array}{c}\text { Drosophila X } \\
\text { virus (DXV) }\end{array}$ & Birnaviridae & dsRNA & DXV-VP3 & SiRNA & $\begin{array}{l}\text { dsRNA binding protein: long } \\
\text { dsRNA \& siRNA duplexes }\end{array}$ \\
\hline \multirow{2}{*}{$\begin{array}{c}\text { Kallithea virus } \\
\text { (KV) }\end{array}$} & \multirow{2}{*}{ Nudiviridae } & \multirow{2}{*}{ dsDNA } & gp83 & Toll & NF- $\kappa B$ transcription factors \\
\hline & & & $?$ & Jak-STAT? & ? \\
\hline \multirow{2}{*}{$\begin{array}{c}\text { Invertebrate } \\
\text { Iridescent virus } 6 \\
\text { (IIV-6) }\end{array}$} & \multirow{2}{*}{ Iridoviridae } & \multirow{2}{*}{ dsDNA } & IIV6-340R & siRNA & $\begin{array}{l}\text { dsRNA binding protein: long } \\
\text { dsRNA \& siRNA duplexes }\end{array}$ \\
\hline & & & ? & IMD/Toll & $\begin{array}{c}\text { Relish-mediated transcriptional } \\
\text { activation/? }\end{array}$ \\
\hline
\end{tabular}

Table 1: Characteristics of the viruses mentioned in the text. 